\title{
Middle to Late Pleistocene radiolarian biostratigraphy in the water-mixed region of the Kuroshio and Oyashio currents, northeastern margin of Japan (JAMSTEC Hole 902-C9001C)
}

\author{
KENJI M. MATSUZAKI ${ }^{1 *}$, NORITOSHI SUZUKI ${ }^{1}$, HIROSHI NISHI $^{2}$, REISHI TAKASHIMA ${ }^{2}$, YUMIKO KAWATE $^{1}$ \& \\ TOYOSABURO SAKAII ${ }^{3}$ \\ ${ }^{1}$ Institute of Geology and Paleontology, Graduate School of Science, Tohoku University Aramaki 6-3, Sendai 980-8578, Japan \\ ${ }^{2}$ The Center for Academic Resources and Archives Tohoku University Museum, Tohoku University, Japan \\ ${ }^{3}$ Geology Department, Faculty of Agriculture, Utsunomiya University, Japan \\ *Corresponding author (e-mail: kenji.m.r.matsuzaki@gmail.com)
}

\begin{abstract}
A continuous Quaternary sediment sequence was recovered from Hole 902-C9001C during the D/V Chikyu 2006 mission along the northeastern margin of Japan. The age and rate of deposition of this core were estimated using calcareous nannofossil biostratigraphy and oxygen isotope curves measured from benthic foraminifera (Uvigerina akitaensis) and dated from $740 \mathrm{ka}$ to the present, a period that spanned the Brunhes normal polarity epoch. Sediment consisted of diatomaceous siltstone and contained an abundance of radiolarians. A total of 91 radiolarian species was found in the core, of which 74 were analysed. Of these radiolarian species, 36 demonstrated continuous stratigraphical distribution over the past $740 \mathrm{ka}$ and 38 had shorter ranges of biostratigraphical interest. Three of the 38 species were determined to be novel and are described in the present study (Amphisphaera tanzhiyuani sp. nov., Schizodiscus japonicus sp. nov. and Siphonosphaera? paraphoros sp. nov.). Based on 17 radiolarian bioevents, including four datums which have been commonly used across a wide area of the North Pacific, the radiolarian sequence of this core was divided into 8 zones: Amphirhopalum virchowii Zone (613-740ka), Spongaster tetras irregularis Zone (516-613 ka), Cyrtidosphaera reticulata Zone (357-516ka), Spongurus cylindricus Zone (238-357 ka), Pterocanium depressum Zone (209-238ka), Spongoliva ellipsoides Zone (131-209ka), Ceratospyris problematica Zone (33-131 ka), and the Acanthodesmia vinculata Zone (0-33 ka).
\end{abstract}

KEYWORDS: Radiolaria, biostratigraphy, Pleistocene, offshore Japan

\section{INTRODUCTION}

The region of the northwestern Pacific located along the northeastern margin of Japan is greatly affected by two warm currents (Kuroshio and Tsugaru currents), a cold current (Oyashio Current) and several deep-water masses. The mixture of nutrient-poor warm currents with nutrient-rich cold water has resulted in the presence of high-productivity water masses in the region, which are known to contain sediments rich in biosiliceous components. Sediments in the northwestern Pacific contain an abundance of well-preserved radiolarians, and radiolarian biostratigraphical schemes in the region have been proposed earlier by Sakai (1980), Kamikuri et al. (2004, 2007) and Motoyama et al. (2004). These studies focused primarily on the Lower to Middle Miocene, and the age resolution of Quaternary radiolarian biostratigraphy remains insufficient. Five Pleistocene radiolarian biozones in the Sea of Okhotsk were proposed by Matul et al. (2002, 2009); however, their studies examined only the past $500 \mathrm{ka}$ and it was presumed that the radiolarian biozones established in the Sea of Okhotsk had been isolated from the rest of the northwestern Pacific by the Kamchatka Peninsula, the Kuril Islands and Hokkaido. In the present study, the drilled core Hole 902-C9001C (Fig. 1) was used to establish a new radiolarian biostratigraphical scheme in the northwestern Pacific for the Brunhes normal polarity epoch (the period spanning the last $740 \mathrm{ka}$ ). This core provided a continuous record of the past $740 \mathrm{ka}$ and has been dated accurately using benthic foraminiferid oxygen isotope stratigraphy (Uvigerina akitaensis) and calcareous nannofossil datums (Domitsu et al. 2011) (Fig. 2). Siliceous microfossils (diatoms and radiolarians) are well preserved down-core. Examination of the stratigraphical distribution and species diversity of radiolarian assemblages within this core resulted in the identification of 91 species. Of the 74 species identified (Fig. 3), 36 occurred continuously through the core, and 38 species, including three novel species, were of biostratigraphical interest. Based on associated bioevents, eight radiolarian zones were established, and the novel biozones identified in the present study were correlated with those that had already been proposed in previous studies (Matul et al. 2002; Kamikuri et al. 2004; Motoyama et al. 2004).

\section{MATERIALS AND METHODS}

Core 902-C9001C was drilled at a water depth of $1180 \mathrm{~m}$ $\left(41^{\circ} 10^{\prime} 38.28^{\prime \prime} \mathrm{N}, 142^{\circ} 12^{\prime} 04.86^{\prime \prime} \mathrm{E}\right)$ during the D/V Chikyu 2006 mission (Fig. 1). The core provided a continuous record from marine isotope stage (MIS) $18(750 \mathrm{ka})$ to the present, a period that spanned the Brunhes normal polarity epoch $(0-740 \mathrm{ka})$. The age model of this core was established through measurement of the stable oxygen isotopes of benthic foraminifera and calcareous nannofossil datums (Domitsu et al. 2011) (Fig. 2). In total, 163 samples were examined for radiolarians. Samples were initially freeze-dried with an Advantec VF-350 Vacuum Freezing Dryer. Dried samples were then disaggregated with hydrogen peroxide and diluted with hydrochloric acid. Undissolved residues within each sample were sieved using a $63 \mu \mathrm{m}$ screen prior to being dried in an oven. Dried residues were subdivided evenly into several aliquots, and one aliquot was embedded with Canada Balsam and used to prepare microscopic slides. Observation of radiolarians was carried out at magnifications of $100-400 \times$ using optical microscopes. The studied material is deposited at the Tohoku University Graduate School of Science, Department of Geology and Paleontology. 


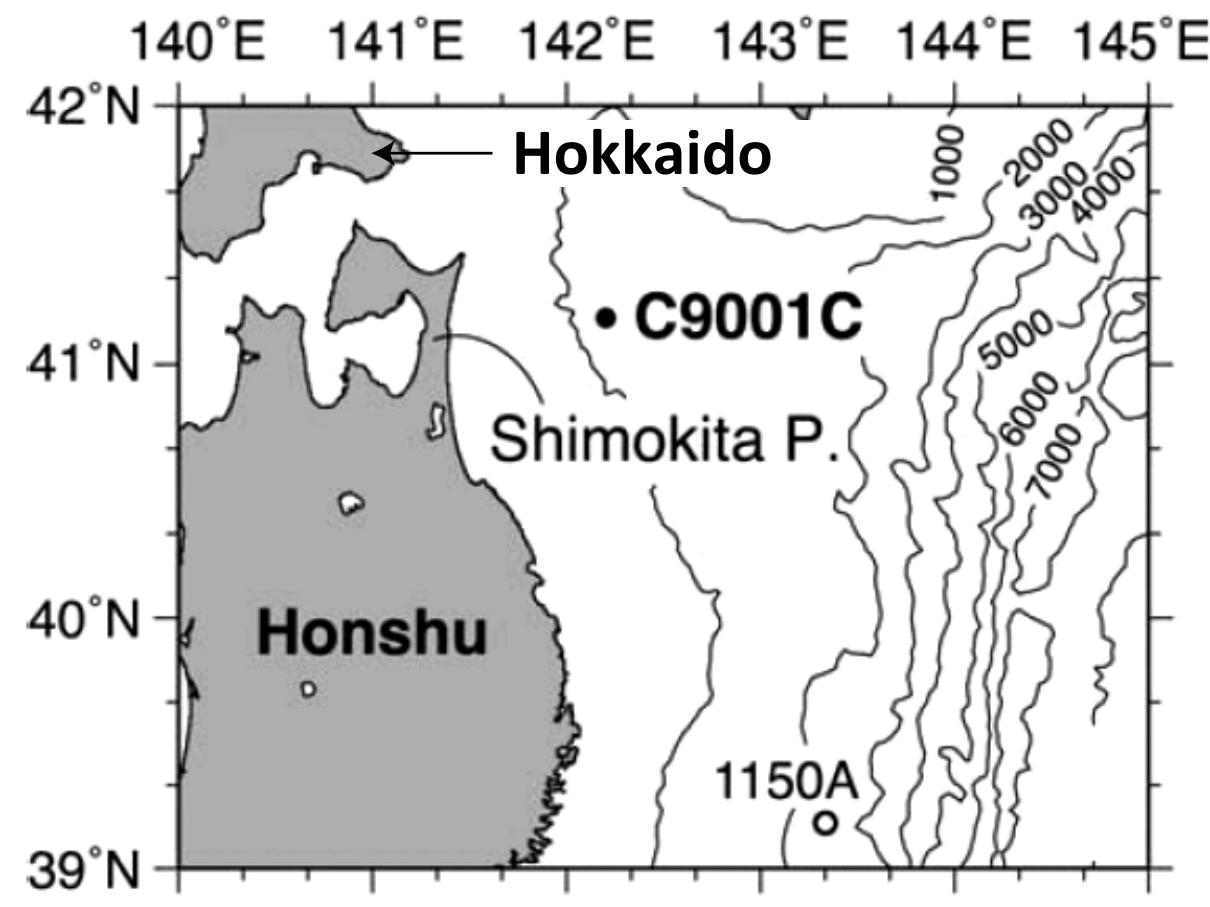

Fig. 1. Location of core $902-\mathrm{C} 9001 \mathrm{C}$ off the west coast of the Shimokita peninsula, NE Japan $\left(41^{\circ} 10^{\prime} 38.28^{\prime \prime} \mathrm{N}, 142^{\circ} 12^{\prime} 04.86^{\prime \prime} \mathrm{E}\right)$.

\section{SYSTEMATIC PALAEONTOLOGY}

Thorough examination of species composition within the 163 samples revealed a total of 91 species (3 collodarians, 51 spumellarians, and 37 nassellarians). Among these species, the stratigraphical distributions of 74 are presented in Figure 3. Forty-eight important species are illustrated (Pls 1-3) and their taxonomic references are listed in Table 1. Of these 48 species, 38 demonstrated sufficiently discontinuous distributions to be biostratigraphically useful. Among these 38 species, three are newly described in detail below.

Class Radiolaria Müller, 1859

Order Collodaria Haeckel, 1882, sensu Petrushevskaya, 1984 Genus Siphonosphaera Müller, 1859

Type species. Siphonosphaera tubulosa Müller, 1859. [Subsequent designation by Campbell, 1954.]

Siphonosphaera? paraphoros Matsuzaki \& Suzuki sp. nov. (Pl. 1, figs 1-4)

Derivation of name. Greek female noun, $\pi \alpha \rho \alpha \varphi \rho \rho \varsigma$, meaning confusing.

Diagnosis. A single cortical shell relatively irregular in shape, platy surface with two types of pores.

Holotype. Plate 1, figure 1; sample 902-C9001C, 10H-1, 45.5$54.5 \mathrm{~m}$ (Middle Pleistocene). Catalogue number IGPS 111417.

Distribution in the NW Pacific. Extant off Shimokita.

Description. A single irregular and platy surface cortical shell bearing two types of pores, the first group comprises several rounded polygonal pores of relatively larger size with a short centrifugal tube, and the second group a small number of irregular pores throughout the platy cortical shell. A hook-like spine is present on some of the larger rounded polygonal pores. No spines or significant projections are present on the cortical shell.

Dimensions. Based on four illustrated specimens: average diameter $135 \mu \mathrm{m}$, maximum diameter $180 \mu \mathrm{m}$ and minimum diameter $100 \mu \mathrm{m}$.

Occurrence. Continuous for the past $740 \mathrm{ka}$, living and fossil (this study).

Remarks. The main difference from Acrosphaera spinosa Haeckel, 1887 is the presence of a short centrifugal tube on each larger pore. This species is morphologically similar to members of the genus Odontosphaera Haeckel, 1887 in that a hook-like spine on some larger pores is present in this new species. However, the characteristic centrifugal tube is present on each larger pore, and thus we tentatively regard this new species as a member of Siphonosphaera.

\section{Order Spumellaria Ehrenberg, 1876}

Genus Amphisphaera Haeckel, 1882 emend. Suzuki et al., $2009 b$

Type species. Amphisphaera (Amphisphaerantha) neptunus Haeckel, 1887.

Amphisphaera tanzhiyuani Matsuzaki \& Suzuki sp. nov.

(Pl. 2, figs 21-24)

1974 Stylatractus pyriformis (Bailey); Kruglikova: 188, 190, figs

2.2, 2.3 [only].

1982 Amphistylus sp. Tan \& Su: 141-142, pl. 3, fig. 10.

1984 ?Stylatractus sp. Nishimura \& Yamauchi: 34, pl. 5, fig. 11. 
Radiolarian biostratigraphy in NE Japan

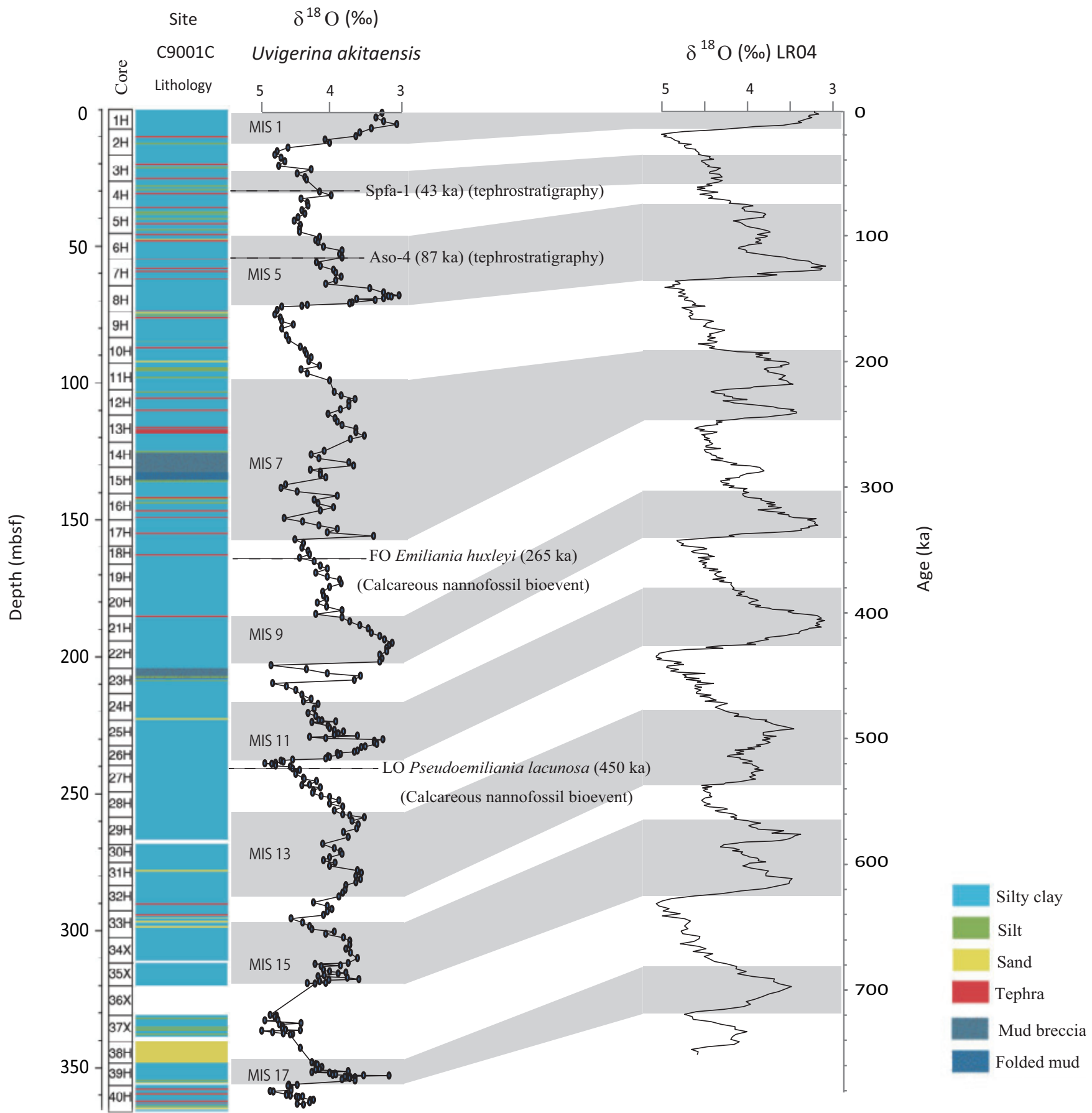

Modified from Domitsu et al. (2011)

Fig. 2. Age model of core 902-9001C. The depositional age of core 902-9001C was established using oxygen isotope measured from benthic foraminifera (Domitsu et al. 2011), calcareous nannofossil datums (FO of Emiliania huxleyi (270 ka) and Pseudoemiliania lacunosa (450 ka)) and tephrostratigraphy datums (Spfa-1 (43 ka) and Aso-4 (87 ka)).

1992 Lithatractus tochigiensis Nakaseko [nomen nudum]; Alexandrovich: pl. 3, fig. 10.

1996 Stylatractus disetanius Haeckel; Chen \& Tan: 177, pl. 11, figs $1-3$; pl. 41 , fig. 5 .
2004 Stylosphaera hispida Ehrenberg; Okazaki et al.: pl. 2, figs $4,5$.

2005 ?Stylatractus pyriformis (Bailey); Abelmann \& Nimmergut: pl. 7, fig. 19 [only]. 


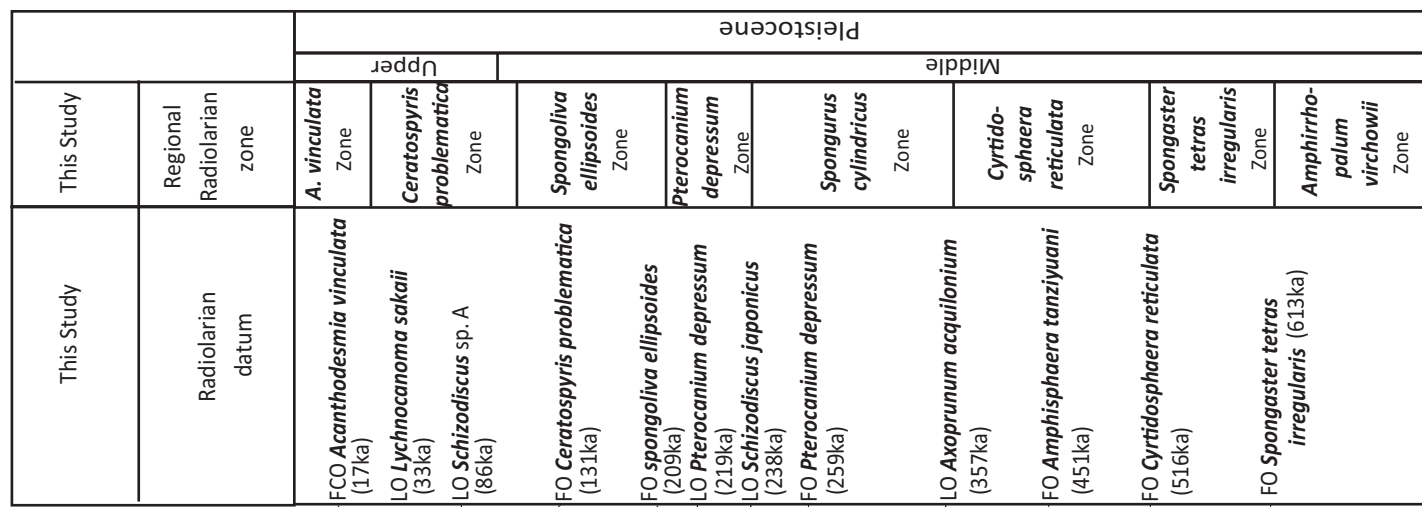

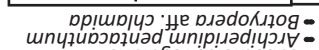

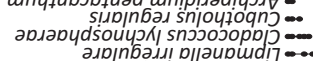

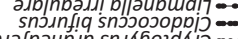

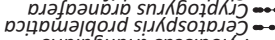

s!lpinbub!it snosipolkd

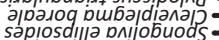

sap!oj!nnuu sn!|ayt!?
unssadda un!upjoxaj

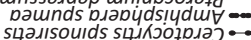

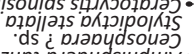

!unn K! yzup? Dגapyds!ydü

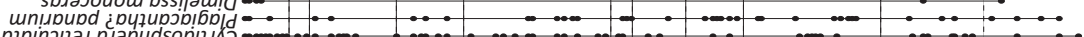

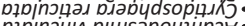

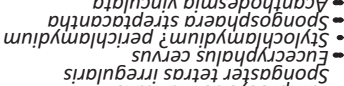

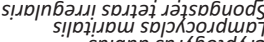

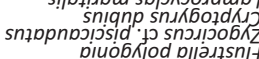

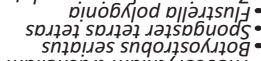

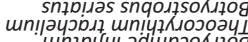

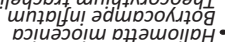

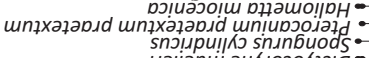

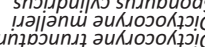

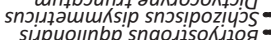

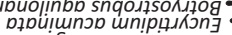

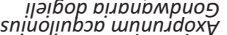

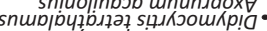

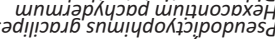

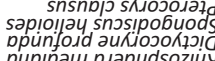

pup!paum pגapydsoz!yy

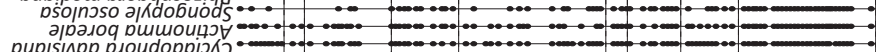

un

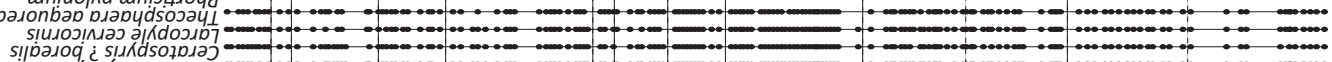

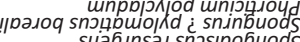

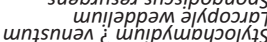

dnoג8 גәןाnw

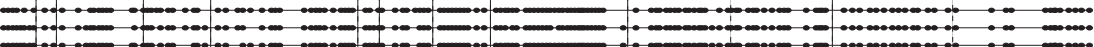

-

10 -

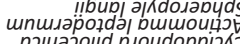

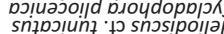

!!pyps pwoupouyगK

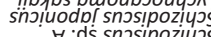

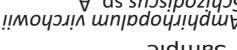

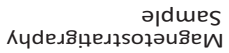
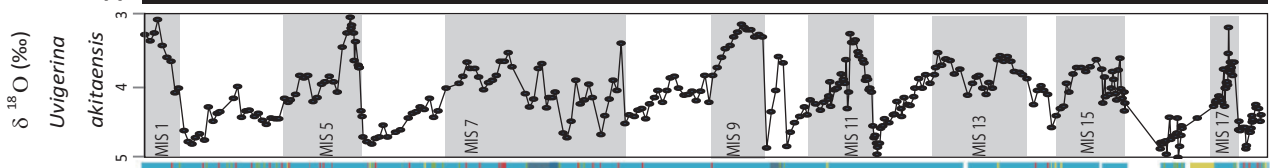

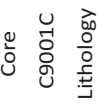

家

ำ

穴

के 
2008 Druppatractus ostracion Haeckel; Tanaka \& Takahashi: pl. 1, fig. 13.

Derivation of name. The name tanzhiyuani is in honour of Dr Tan Zhiyuan, one of the authors of the classic paper, Tan \& Su (1982), which figured this species.

Diagnosis. Three concentric shells marked by numerous radial beams bearing two long cylindrical bipolar spines.

Holotype. Plate 2, figure 21; sample 902-C9001C, 29H-1, 47-53 (Middle Pleistocene). Catalogue number IGPS 111418.

Distribution in the NW Pacific. Bering Sea, East China Sea, Sea of Japan, Nankai Trough, Sea of Okhotsk, South China Sea, east off Shimokita; living and fossil.

Description. Three concentric shells with two long, cylindrical, bipolar spines. Innermost shell is a spherical microsphere with numerous radial beams. The second shell is a spherical macrosphere with numerous radial beams. The third shell is the first cortical shell with a spherical or rather oblong spherical shape. The surface of the third shell is neither rough nor smooth. The wall of the first cortical shell is thick in the mature form and the wall thickness is equal everywhere. Pores are hexagonal in shape and are arranged as six to seven pores in both the longitudinal and equatorial axes of the cortical shell. The pore frame tends to be robust, but pores always appear to be visible even in mature forms. Bipolar spines are thin, generally equal in length and are cylindrical or subcylindrical in cross-section. The ratio of the diameters of the microsphere, macrosphere and cortical shell is $1: 2.8-2.2: 3.8-4.2$. Radial beams connecting between the cortical shell and macrosphere are visible as black, solid bars under transmitted light microscopy.

Dimensions. Based on 10 specimens, for axial diameter, diameter at the external cortical shell equator and the maximum and minimum diameters of the inner shell. Minimum axial diameter is $70 \mu \mathrm{m}$ whilst maximum is $100 \mu \mathrm{m}$; average axial diameter is $86 \mu \mathrm{m}$. External cortical shell's equatorial diameter is between 70 and $90 \mu \mathrm{m}$ and average is $78 \mu \mathrm{m}$. Inner shell maximum diameter fluctuates between 40 and $55 \mu \mathrm{m}$; average diameter is $51 \mu \mathrm{m}$. Minimum inner shell diameter ranges from 40 to $50 \mu \mathrm{m}$; average $42 \mu \mathrm{m}$.

Occurrence. From 451 to $0 \mathrm{ka}$ at this site. Extant species.

Remarks. Amphisphaera gracilis Campbell \& Clark, 1944 is similar to this morphotype, but the former differs from the latter by having significantly bladed bipolar spines. This morphotype has no similarity to Stylosphaera hispida Ehrenberg. S. hispida has only two shells, a pear-shaped macrosphere and an ellipsoid cortical shell. The pear-shaped macrosphere is connected to the cortical shell by six radial beams. This morphotype is occasionally misidentified as Stylosphaera pyriformis (Bailey), but is easily distinguished from the latter by having numerous thick radial beams between the cortical shell and the macrosphere and the presence of an ellipsoid macrosphere instead of a heteropolar macrosphere as in S. pyriformis.
Genus Schizodiscus Dogiel in Dogiel \& Reshetnyak, 1952

Type species. Schizodiscus disymmetricus Dogiel in Dogiel \& Reshetnyak, 1952. [Subsequent designation by Ling, 1972.]

Schizodiscus japonicus Matsuzaki \& Suzuki sp. nov. (Pl. 2, figs 27-30)

1973 Spongodiscus sp. Ling: 778, pl. 1, figs 9, 10.

1975 Spongodiscus sp. Ling: pl. 4, fig. 5; Ling, 1980: 368, pl. 1, fig. 7.

1980 Spongodiscus sp. Sakai: 709, pl. 6, fig. 5.

2002 Spongodiscus sp. Matul et al.: 30, figs 4.3, 4.4.

Diagnosis. The diagnosis of this new species is fully cited in Ling (1973, p. 778). The morphological characters of this morphotype are concordant with the description of Spongodiscus sp. in Ling (1973): discoidal biconvex shell whose surface consists of an irregular network with circular to subcircular pores approximately uniform in size and a darker central part.

Holotype. Plate 2, figure 30; sample 902-C9001C, 20H-3, 62-68 (Middle Pleistocene).

Catalogue number IGPS 111419.

Distribution in the NW Pacific. Bering Sea, east off Sanriku, Sea of Okhotsk, east off Shimokita; fossil.

Description. Large inflated, opaque discoidal skeleton with flat sides presenting a porous structure. The pores are circular to subcircular and their sizes fluctuate between 8 and $11 \mu \mathrm{m}$. The central part of the disk is one-half to two-thirds of the diameter of the disc and appears darker than the rest of the shell, suggesting a thickening of the test. The diameter of this central part fluctuates from 70 to $100 \mu \mathrm{m}$ and is also finely pored. The observed specimens were marked by an absence of spines while the siliceous microfossil preservation was good down-core. The absence of spines in the periphery of the skeleton is a strong taxonomic feature of Schizodiscus japonicus. The skeleton periphery is also marked by an absence of pylome for most of the encountered specimens; however, some specimens present a rounded tube-like aperture continuing inside the disk, close to a pylome, illustrated in Plate 2, figs 29-30.

Dimensions. Based on 20 specimens, average diameter is $237 \mu \mathrm{m}$; maximum size $260 \mu \mathrm{m}$ and minimum $200 \mu \mathrm{m}$.

Occurrence. Middle Pleistocene only in this site.

Remarks. To establish the genus of this new species, comparisons were made with the type of the Schizodiscus genus which is S. symmetricus Dogiel \& Reshetnyak (1952). This genus is characterized by a convex, dark and thick central part and slightly inflated disk margins. The skeletons comprise a porous structure defined by small, circular to subcircular, almost uniform pores. The pylome tube is present and extends to the central dark part of the disk. Based on this description, Schizodiscus japonicus seems to conform to the generic definition proposed by Dogiel \& Reshetnyak (1952), except that the pylome is ambiguous in 

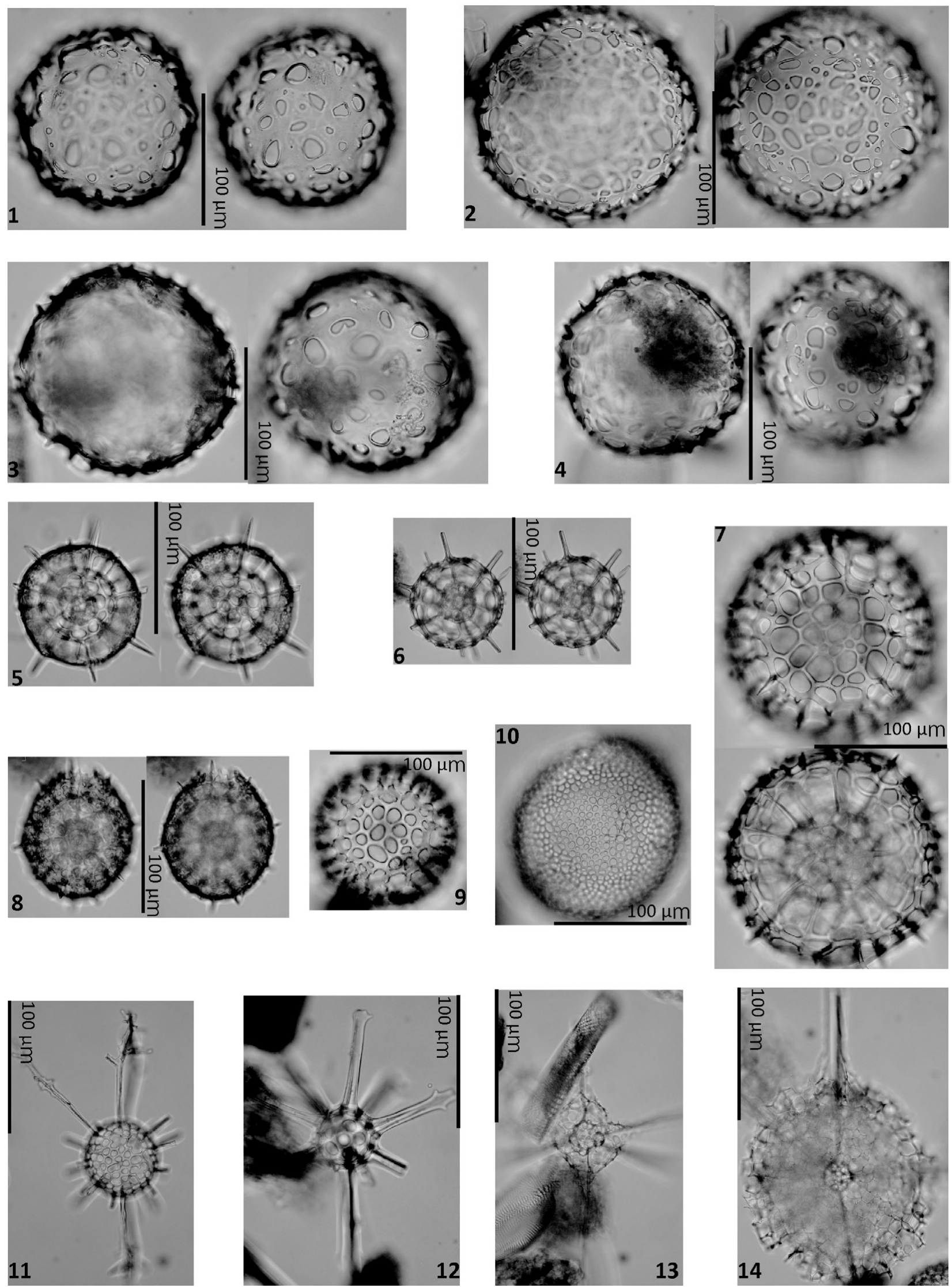
this new species. Dogiel \& Reshetnyak (1952) defined a clear tubiform pylome as a strong taxonomic feature that characterizes Schizodiscus. In our study (e.g. Pl. 2, figs 29-30), individuals were observed with a notch that can be associated with a pylome. However, this pylome feature is not observed in all the specimens (see P1. 2, figs 27-28). Overall, the morphology of Schizodiscus japonicus seems to be close to Schizodiscus definitions and, based on present knowledge, thi $\backslash$ s genus is the most suitable.

Schizodiscus japonicus differs from S. stylotrochoides Dogiel by the absence of the short, main spine system and coronet, and differs from $S$. spatangus Dogiel by the absence of numerous short spines distributed in the disc periphery. S. stylotrochoides Dogiel is marked by a coronet, several relatively thick and short spines, while $S$. spatangus Dogiel possesses numerous fine, short spines and an absence of coronet. Schizodiscus sp. A (Pl. 2, fig. 26 ) is distinguishable from $S$. japonicus by the presence of many equatorial radial spines originating from the central part of the test, a finer test pore frame, and the presence of a thin cover over the central to medial regions of the disk. S. japonicus is completely different from Spongodiscus biconcavus Haeckel, 1887 in having very coarse pores.

\section{CHARACTERISTICS OF RADIOLARIAN ASSEMBLAGES}

Biostratigraphical interpretation was carried out using fractions greater than $63 \mu \mathrm{m}$. Figure 3 shows the 74 species included in subsequent examination. The present study revealed that 36 of the species examined occurred throughout the examined intervals (over the past $740 \mathrm{ka}$ ), while the remaining 38 species showed discontinuous occurrences throughout those same intervals. The assemblages were dominated by the continuous occurrences of pylonioid spumellarians (including Larcopyle buetschlii Dreyer, 1889, Tetrapyle octacantha group Müller, 1859, Phorticium pylonium Jørgensen, 1899, Phorticium polycladum Tan \& Tchang, 1976 and Tholospira cervicornis Haeckel, 1887), flat-shaped spumellarians (Stylochlamydium? venustum (Bailey, 1856), Spongodiscus resurgens Ehrenberg, 1854, Schizodiscus japonicus sp. nov. and Spongodiscus helioides (Cleve, 1899)) and spherical spumellarians (including Actinomma boreale Cleve, 1899 and A. leptodermum (Jørgensen, 1899)). Episodic occurrences of three flat, triangular-shaped radiolarians, Dictyocoryne profunda Ehrenberg, 1873a, D. truncatum (Ehrenberg, 1862) and D. muelleri (Haeckel, 1862), and one spherical species, Haliommetta miocenica (Campbell \& Clark, 1944), were also observed. In contrast to the high species diversity of Spumellaria, the diversity of Nassellaria appeared low. Both Cycladophora davisiana Ehrenberg, 1862 and Ceratospyris? borealis (Bailey, 1856) occurred throughout the intervals examined. Based on the distribution of the 74 species examined, 12 bioevents within core 902-C9001C were recognized as biostratigraphically useful (Fig. 3). First occurrence (FO) datums were detected at
- $613 \mathrm{ka}$ (FO of Spongaster tetras Ehrenberg, 1862 irregularis Nigrini, 1967),

- $516 \mathrm{ka}$ (FO of Cyrtidosphaera reticulata Haeckel, 1861a),

- $451 \mathrm{ka}$ (FO of Amphisphaera tanzhiyuani sp. nov.),

- $259 \mathrm{ka}$ (FO of Pterocanium depressum Ehrenberg, 1873a),

- $209 \mathrm{ka}$ (FO of Spongopila ellipsoides Popofsky, 1912), and

- $131 \mathrm{ka}$ (FO of Ceratospyris problematica (Dogiel in Petrushevskaya, 1969)).

A first continuous occurrence (FCO) datum was recorded at $17 \mathrm{ka}$ (for Acanthodesmia vinculata (Müller, 1859)) and five last occurrence (LO) datums were identified at

- $357 \mathrm{ka}$ (LO of Axoprunum acquilonium (Hays, 1970)),

- $238 \mathrm{ka}$ (LO of Schizodiscus japonicus sp. nov.),

- $219 \mathrm{ka}$ (LO of Pterocanium depressum),

- $86 \mathrm{ka}$ (LO of Schizodiscus sp. A), and

- $33 \mathrm{ka}$ (LO of Lychnocanoma sakaii Morley \& Nigrini, 1995).

The relative abundance of $L$. sakaii changed significantly throughout this core and provided five additional datums: three abundance peaks at 229, 207 and $61 \mathrm{ka}$, a rapid increase datum at $240 \mathrm{ka}$ and a rapid decrease datum at $55 \mathrm{ka}$.

\section{RADIOLARIAN BIOEVENTS}

In the present study 12 bioevents were identified over the past $740 \mathrm{ka}$. Of these events, nine were identified for the first time in core 902-C9001C (Fig. 5), while the remaining three events had been identified previously as useful datums within the northwestern Pacific. Table 2 summarizes the stratigraphical horizons of the 12 bioevents and their correlative numerical ages with oxygen isotope stratigraphy. The correlation of datums with other regions is described in detail below.

\section{Last occurrence datum of Axoprunum acquilonium (357 ka)}

A. acquilonium has been recorded only in North Pacific sediment (e.g. Hays, 1970; Morley et al. 1995), including the Bering and Japan seas (Ling, 1973) and the Sea of Okhotsk (Matul et al. 2002). Hays (1970) and Ling (1973) noted that the relative abundance of this taxon never exceeded $5 \%$ in the Lower to Middle Pleistocene intervals. The LO datum of this taxon was identified at $310 \mathrm{ka}$ in the North Pacific (Hays, 1970), at around $330 \mathrm{ka}$ in the northwestern Pacific (Morley et al. 1995) and at $329 \mathrm{ka}$ in the Sea of Okhotsk (Matul et al., 2002). The LO of A. acquilonium in the present study was located between sample $23 \mathrm{H}-5,54-60 \mathrm{~cm}$ (208.97 mbsf) and sample $24 \mathrm{H} 1-1,25-31 \mathrm{~cm}(213.16 \mathrm{mbsf})$ at $357 \mathrm{ka}$ (Table 2). The LO of $A$. acquilonium identified in the present study appeared to be roughly synchronous with the LO previously identified in the northwestern Pacific, revealing a time gap of less than $27 \mathrm{ka}$.

Explanation of Plate 1. figs 1-4. Collodaria: 1-4, Siphonosphaera? paraphoros sp. nov., holotype, fig. 1, IGPS 111417, sample 902-C9001C, 10H-1, 45.5-54.5 and 11H-3, 50.5-59.5. figs 5-14. Spumellaria: 5, Actinomma boreale (Cleve), sample 902-C9001C, 21H-4, 47-53; 6, Actinomma leptodermum (Jørgensen), sample 902-C9001C, 19H-6, 47-53; 7, Rhizosphaera mediana (Nigrini), sample 902-C9001C, 1H-1, 24-30; 8, Sphaeropyle langii Dreyer, 29H-4, 47-53; 9, Cenosphaera? sp., sample 902-C9001C, 7H-5, 45.5-54.5; 10, Cyrtidosphaera reticulata Haeckel, sample 902-C9001C, 7H-5, 45.5-54.5; 11, Cladococcus bifurcus Haeckel, sample 902-C9001C, 1H-2, 50-56; 12, Cladococcus lychnosphaerae, sample 902-C9001C, 1H-2, 50-56; 13, Cleveiplegma boreale (Cleve), sample 902-C9001C, 1H-5, 30-36; 14, Spongosphaera streptacantha Haeckel, sample 902-C9001C, 2H-2, 50-56. 
Last occurrence datum of Schizodiscus japonicus (238 ka)

Schizodiscus japonicus sp. nov. has long been referred to as Spongodiscus sp. (e.g. Ling, 1973) and its LO has been recognized in the Middle Pleistocene at sites in the northwestern Pacific (Ling, 1973; Sakai, 1980; Matul et al. 2002). The numerical age of this datum was roughly estimated at $290 \mathrm{ka}$ by Matul et al. (2002) in the Sea of Okhotsk. Based on benthic foraminiferal oxygen isotopic stratigraphy, the LO age at the site examined in the present study was estimated at $238 \mathrm{ka}$ (Fig. 5), which revealed a time gap of $62 \mathrm{ka}$ between this site and the site examined by Matul et al. (2002). These results left no doubt that the LO of $S$. japonicus was located in the upper Middle Pleistocene at sites in the North Pacific.

\section{Stratigraphical events of Lychnocanoma sakaii}

The LO of $L$. sakaii was the most recent of the radiolarian bioevents identified from larger radiolarian fractions $(>63 \mu \mathrm{m})$ in the North Pacific (Sakai, 1980). According to Sachs (unpublished thesis, Brown University, 1973), this datum served as a useful bioevent in Pleistocene deep-sea sediments. In this section the L. sakaii curve will be presented as a stratigraphical proxy based on Figure 4.

\section{Rapid decrease datum $(50 \mathrm{ka})$ and last occurrence datum (33 ka) of L. sakaii.}

The FO of L. sakaii was not detected in core 902-C9001C as the base of the core is only $740 \mathrm{ka}$, and the FO of L. sakaii is recognized at $1.6 \mathrm{Ma}$ by both Morley \& Nigrini (1995) and Kamikuri (2010). The LO of L. sakaii was detected here in the interval between sample $3 \mathrm{H}-4,42-48 \mathrm{~cm}(20.91 \mathrm{mbsf})$ and sample $3 \mathrm{H}-6$, $50-56 \mathrm{~cm}$ (23.74 mbsf), which corresponds to $33 \mathrm{ka}$ (Table 1). According to several previous studies (Robertson, unpublished thesis, Columbia University, 1975; Morley \& Nigrini, 1995; Kamikuri, 2010), the LO of this species was dated at $50 \mathrm{ka}$, while Matul et al. (2002) dated the LO of L. sakaii at $29 \mathrm{ka}$ in the Sea of Okhotsk, and Morley et al. (1982) dated the LO between 16.7 and $34 \mathrm{ka}$. The LO of the species identified in the present study appeared to be similar to the LOs identified by Morley et al. (1982) and Matul et al. (2002). The long time gap between our $L$. sakaii LO datum of $33 \mathrm{ka}$ and that identified in the records of Robertson (unpublished thesis, Columbia University, 1975), Morley \& Nigrini (1995) and Kamikuri (2010) at around $50 \mathrm{ka}$ requires examination. This date is almost the same as that at which the present study identified a rapid decrease datum (RD, Fig. 4). This phenomenon could have been plausibly interpreted as a LO in a low resolution study, while in a high resolution study
- as the present study and that of Matul et al. (2002) - the RD datum and LO appear as two distinct events.

2. Rapid increase datum (240 ka) and abundance peaks (61, 207 and $229 \mathrm{ka}$ ) of Lychnocanoma sakaii.

As shown in Figure 4, the change in relative abundance of $L$. sakaii was so significant that the rapid increase (RI) datum and abundance peaks (AP) of this species were potentially applicable to biostratigraphical correlation with adjacent regions. This significance had already been noted for the North Pacific by Sachs (unpublished thesis, Brown University, 1973); however, in that study, L. sakaii was identified as Lychnocanoma grande Campbell \& Clark, 1944. In the present study, one RID and three APs higher than $10 \%$ of the total assemblages were identified at 240 , 229, 207 and $61 \mathrm{ka}$, respectively (Fig. 4, Table 3). The highest relative abundance peak of $L$. sakaii during the last $740 \mathrm{ka}$ (AP3) was located at $61 \mathrm{ka}$ during the early MIS 4. This event was detected at $60 \mathrm{ka}$ in the northwestern Pacific by Robertson (unpublished thesis, Columbia University, 1975) and Sachs (unpublished thesis, Brown University, 1973), while Matul et al. (2002) recorded a high abundance peak for $L$. sakaii in the Sea of Okhotsk at $72 \mathrm{ka}$. L. sakaii AP3 appears to be a suitable age tie point in the northwestern Pacific.

\section{RADIOLARIAN ZONATION}

As documented in the previous sections, 12 bioevents were detected in 902-C9001C (Fig. 3). Among these bioevents, nine were recognized for the first time in core 902-C9001C (FOs of Spongaster tetras irregularis, Cyrtidosphaera reticulata, Amphisphaera tanzhiyuani, Pterocanium depressum, Spongoliva ellipsoides and Ceratospyris problematica; FCO of Acanthodesmia vinculata; LOs of Axoprunum acquilonium and Schizodiscus sp. A). Among these nine bioevents, seven define eight new radiolarian interval zones at the Shimokita site (Fig. 3). The LO of Schizodiscus sp. A was not selected as a zonal marker since identification proved difficult due to its strong morphological similarities with other species, although Schizodiscus japonicus is separated from other Schizodiscus species by the absence of radial spines around the disk and significant light contrast between the central part and its adjacent exterior thinner part of the disk (Dogiel \& Reshetnyak, 1952; Petrushevskaya, 1968). The remaining bioevents could potentially be used subordinately for refinement and confirmation of age determinations using the zones proposed in the present study.

Explanation of Plate 2. figs 1-30. Spumellaria: 1-2, Tetrapyle octacantha Müller group, sample 902-C9001C, 1H-2, 50-56 and 16H-8, 62-68; 3, Phorticium polycladum Tan \& Tchang, sample 902-C9001C, 16H-8, 62-68; 4, Phorticium pylonium Haeckel, sample 902-C9001C, 20H-3, 62-68; 5, Pylodiscus triangularis Haeckel, sample 902-C9001C, 1H-2, 50-56; 6-7, Larcopyle buetschlii Dreyer, sample 902-C9001C, 1H-2, 50-56 and 16H8, 62-68; 8, Larcopyle cervicornis Haeckel, 11H-5, 45.5-54.5; 9, Tholomura plystyla (Chen) comb. nov. sample 902-C9001C, 1H-2, 50-56; 10, Lithelius nautiloides Popofsky, sample 902-C9001C, 10H-6, 45.5-54.5; 11, Spongoliva ellipsoides Popofsky, sample 902-C9001C, 1H-1, 29-30; 12, Amphirhopalum virchowii (Haeckel), sample 902-C9001C, 21H-4, 47-53; 13, Dictyocoryne profunda Ehrenberg, sample 902-C9001C, 22H-4, 47-53; 14, Dictyocoryne muelleri (Haeckel), sample 902-C9001C, 12H-4, 20.5-29.5; 15, Dictyocorine truncatum (Ehrenberg), sample 902-C9001C, 27H6, 69-75; 16, Spongaster tetras Ehrenberg irregularis Nigrini, sample 902-C9001C, 1H-5, 30-36 ; 17, Stylochlamydium? venustum (Bailey), sample 902-C9001C, 22H-4, 47-53; 18, Heliodiscus cf. tunicatus O’Connor, sample 902-C9001C, 19H-6, 47-53; 19, Axoprunum aquilonium (Hays), sample 902-C9001C, 39H-5, 57-63 ; 20, Amphisphaera spumea (Dumitrica), sample 902-C9001C, 29H-4, 47-53; 21-24, Amphisphaera tanzhiyuani sp. nov., holotype, fig. 21, IGPS 111418, sample 902-C9001C, 29H-1, 47-53 and 29H-3, 47-53; 25, Spongodiscus helioides (Cleve), sample 902-C9001C, 1H-5, 30-36; 26. Schizodiscus sp. A, sample 902-C9001C, 10H-6, 45.5-54.5; 27-30, Schizodiscus japonicus sp. nov., holotype, fig. 30, IGPS 111419, sample 902-C9001C, 20H-3, 62-68. 

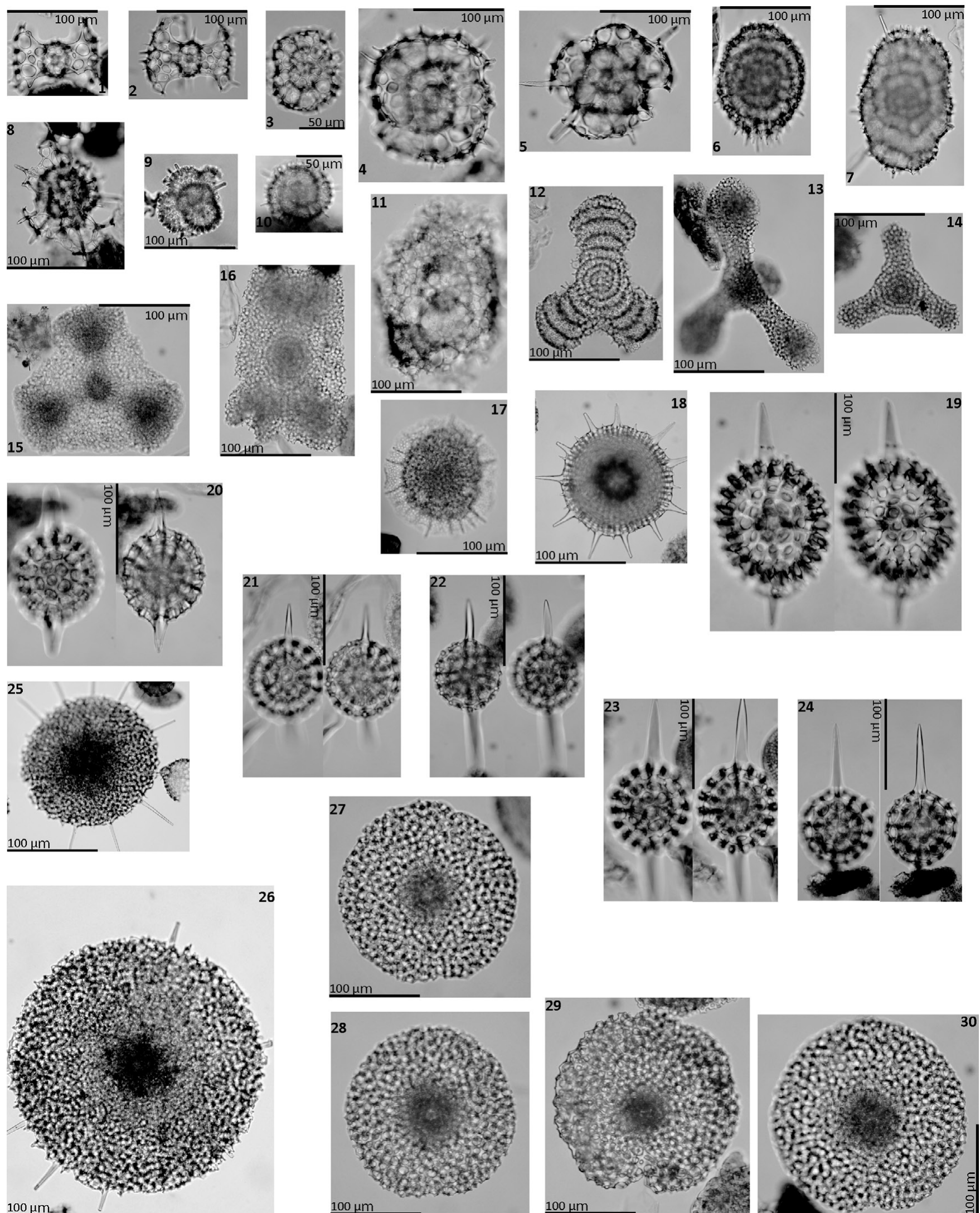
Amphirhopalum virchowii Interval Zone (bottom of core-613 ka)

Definition. Base of zone is not defined. Top of zone defined by base of Spongaster tetras irregularis Interval Zone.

Faunal character. The assemblage is marked by continuous occurrences of Tetrapyle octacantha, Larcopyle buetschlii, Stylochlamydium? venustum and Cycladophora davisiana.

Interval and age. The stratigraphical interval between sample $40 \mathrm{H}-10$ at $55-61 \mathrm{~cm}(362 \mathrm{mbsf})$ and $35 \mathrm{X}-5$ at $47-53 \mathrm{~cm}(316 \mathrm{mbsf})$ in the $902-\mathrm{C} 9001 \mathrm{C}$ core. This zone covers the period from the core base to $613 \mathrm{ka}$.

\section{Spongaster tetras irregularis Interval Zone (613-516 ka)}

Definition. Base of zone defined by FO of Spongaster tetras irregularis. Top of zone defined by base of Cyrtidosphaera reticulate Interval Zone.

Faunal character. Assemblage is marked by the continuous occurrence of Tetrapyle octacantha, Larcopyle buetschlii, Stylochlamydium? venustum and Cycladophora davisiana, as in the previous zone. The FOs of Spongosphaera streptacantha and Eucecryphalus cervus are placed in this zone.

Interval and age. The stratigraphical interval between sample 35X-5, $47-53 \mathrm{~cm}(316 \mathrm{mbsf})$ and $31 \mathrm{H}-2,25-31 \mathrm{~cm}(275 \mathrm{mbs})$ in the 902-C9001C core. This zone covers the period from 613 to $516 \mathrm{ka}$.

Remarks. The FO of Spongaster tetras irregularis is recorded at the top of the Stylatractus universus Zone (Lower PleistoceneMiddle Pleistocene) in Morley (1985). In our site, this datum is found in MIS 15.

\section{Cyrtidosphaera reticulata Interval Zone (516-357 ka)}

Definition. Base of zone defined by the FO of Cyrtidosphaera reticulata. Top of zone defined by the base of the Spongurus cylindricus Interval Zone.

Faunal character. The assemblage is marked by the continuous occurrence of Tetrapyle octacantha, Larcopyle buetschlii, Stylochlamydium? venustum and Cycladophora davisiana from the Amphirhopalum virchowii Zone. The FO of Amphisphaera tanzhiyuani sp. nov (451 ka) is placed in this zone, but it cannot be used as a biostratigraphical marker because of limited geographical coverage.

Interval and age. The stratigraphical interval between sample $31 \mathrm{H}-2$ at $25-31 \mathrm{~cm}(275 \mathrm{mbsf})$ and $23 \mathrm{H}-5$ at $54-60 \mathrm{~cm} \mathrm{(208} \mathrm{mbsf)}$ in the $902-\mathrm{C} 9001 \mathrm{C}$ core. This zone covers the period from 516 to $357 \mathrm{ka}$.
Spongurus cylindricus Interval Zone (357-238 ka)

Definition. Base of zone defined by the LO of Axoprunum acquilonium. Top of zone defined by the base of Pterocanium depressum Interval Zone.

Faunal character. The characteristic species in this zone are the same as in the Spongaster tetras irregularis Zone. In addition, the first occurrence (FO) of Pterocanium depressum (259ka) is the key marker of this zone.

Interval and age. The stratigraphical interval between sample $23 \mathrm{H}-5$ at $54-60 \mathrm{~cm}$ (208 mbsf) and $17 \mathrm{H}-2$ at $24-30 \mathrm{~cm}$ (149.8 mbsf) in the 902-C9001C core. This zone covers the period from 357 to $238 \mathrm{ka}$.

Pterocanium depressum Interval Zone (238-209ka)

Definition. Base of zone defined by the LO of Schizodiscus japonicas sp. nov.. Top of zone defined by the base of Spongoliva ellipsoides Interval Zone.

Faunal character. The important taxa are the same as in the previous zones, except for the disappearance of Pterocanium depressum (LO at $219 \mathrm{ka}$ ), Schizodiscus japonicas sp. nov. (LO at $238 \mathrm{ka})$, Amphirhopalum virchowii and Amphisphaera tanzhiyuani sp. nov. within this zone (Fig. 5).

Interval and age. The stratigraphical interval between sample $18 \mathrm{H}-4$ at $42-48 \mathrm{~cm}(163.04 \mathrm{mbsf})$ and $13 \mathrm{H}-6$ at $40.5-49.5 \mathrm{~cm}$ (118 mbsf) in the 902-C9001C core. This zone covers the period from 238 to $209 \mathrm{ka}$.

Remarks. The last occurrence of Amphirhopalum virchowii is not the true extinction event world-wide, because this species is extant based on the type locality of specimens collected from modern seawater (Sakai et al. 2009).

\section{Spongoliva ellipsoides Interval Zone (209-131 ka)}

Definition. Base of zone defined by the FO of Spongoliva ellipsoides. Top of zone defined by base of Ceratospyris problematica Interval Zone.

Faunal character. The assemblage is characterized by the same species as in the previous zones, except for the occurrence of Cleveiplegma boreale, Spongoliva ellipsoides and Pylodiscus triangularis (Fig. 3).

Interval and age. The stratigraphical interval between sample $13 \mathrm{H}-6$ at $40.5-49.5 \mathrm{~cm} \quad(118 \mathrm{mbsf})$ and $8 \mathrm{H}-6$ at $42-48 \mathrm{~cm}$ (70.85 mbsf) in the $902-\mathrm{C} 9001 \mathrm{C}$ core. This zone covers the period from 209 to $131 \mathrm{ka}$.

Explanation of Plate 3. figs 1-19. Nassellaria: 1, Botryopera aff. chlamida Petrushevskaya, sample 902-C9001C, 1H-2, 50-56; 2, Archiperidium pentacanthum (Popofsky), sample 902-C9001C, 1H-2, 50-56; 3, Cryptogyrus araneafera (Popofsky), sample 902-C9001C, 4H-6, 69-75; 4, Cryptogyrus dubius (Dogiel in Dogiel \& Reshetnyak), sample 902-C9001C, 4H-6, 69-75; 5, Dimelissa monoceras (Popofsky), sample 902-C9001C, 1H-2, 50-56; 6, Zygocircus cf. piscicaudatus Popofsky, sample 902-C9001C, 7H-5, 45.5-54.5; 7, Acanthodesmia vinculata (Müller), sample 902-C9001C, 1H-1, 24-30; 8, Ceratospyris? borealis Bailey, sample 902-C9001C, 2H-2, 50-56; 9, Ceratospyris problematica (Dogiel in Petrushevskaya), sample 902-C9001C, 1H-5, 30-36; 10-12, Cycladophora davisiana Ehrenberg, sample 902-C9001C, 2H-1, 55-61 and 7H-2, 53.5-62.5; 13, Lipmanella irregulare (Cleve), sample 902-C9001C, 1H-5, 30-36; 14, Theocorythium trachelium (Ehrenberg), sample 902-C9001C, 30H-2, 77-83; 15, Ceratocyrtis spinosiretis (Takahashi), sample 902-C9001C, 2H-2, 50-56; 16, Lamprocyclas maritalis Haeckel, sample 902-C9001C, 29H-1, 47-53; 17, Pterocanium depressum (Ehrenberg), sample 902-C9001C, 13H-2, 45.5-54.5; 18-19, Lychnocanoma sakaii Morley \& Nigrini, sample 902-C9001C, 8H-4, 26-32 and 13H-2, 45.5-54.5. 

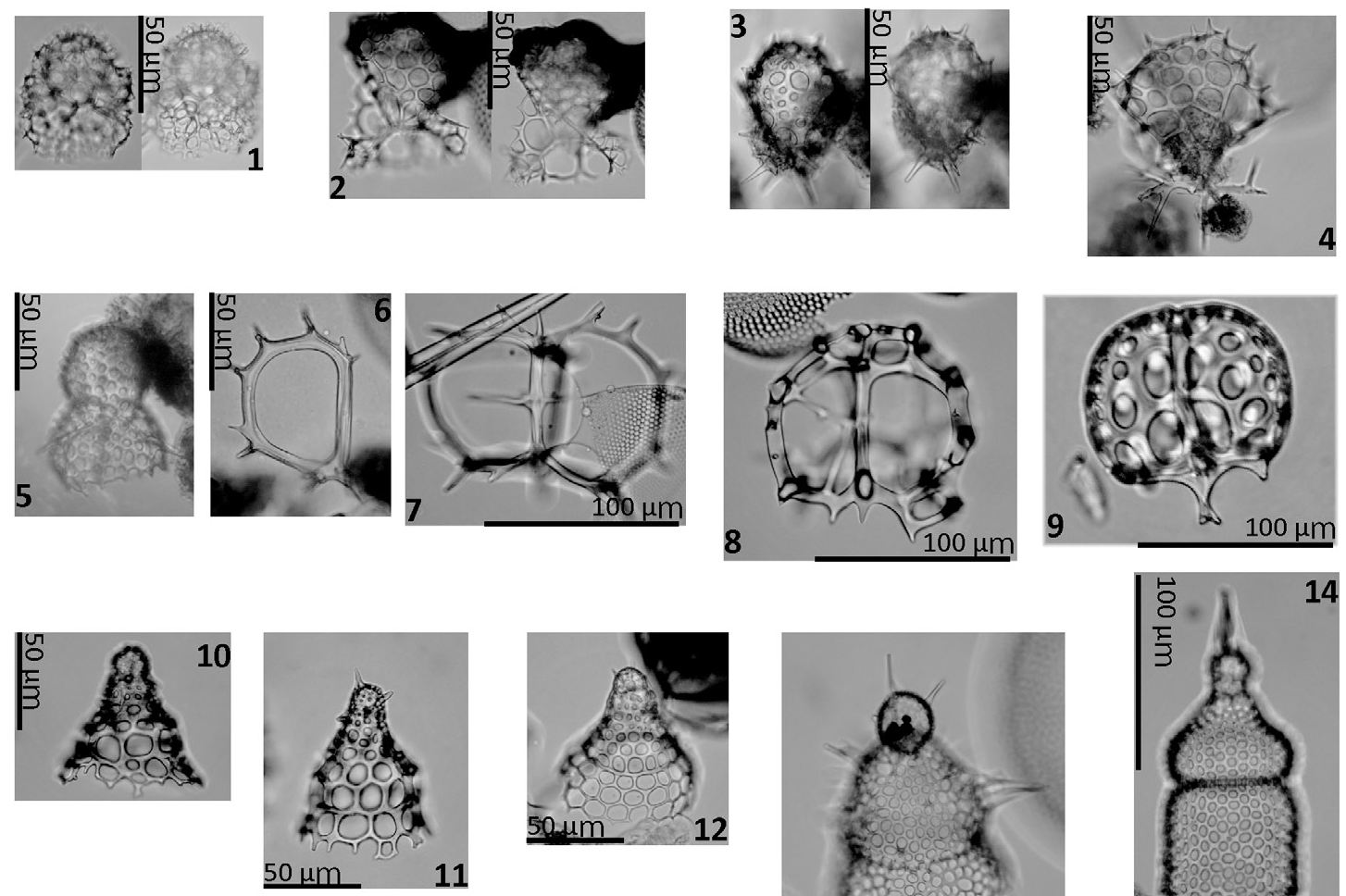

11
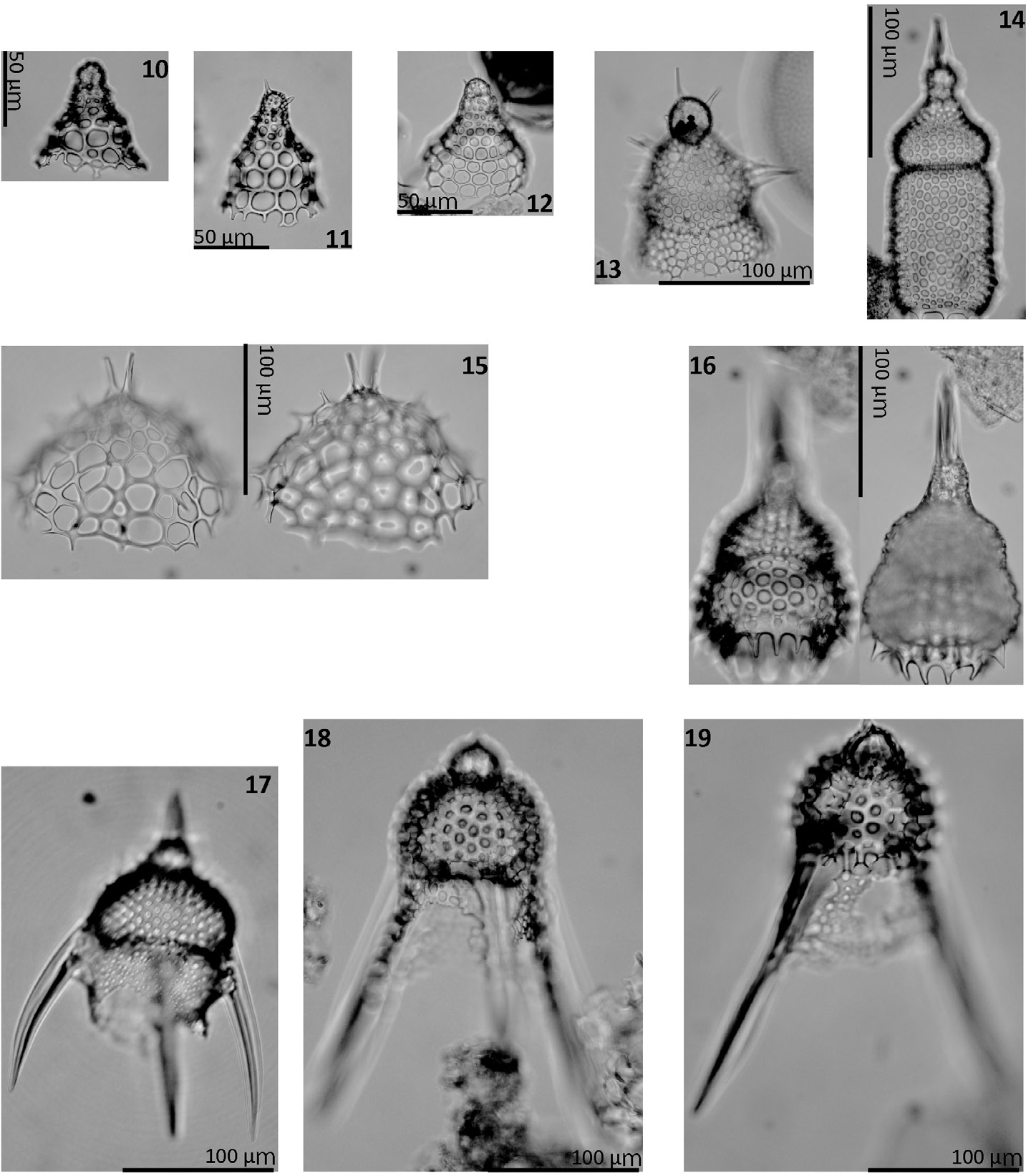
Table 1. Species list and authors of the biostratigraphically important radiolarian species in core 902-9001C.

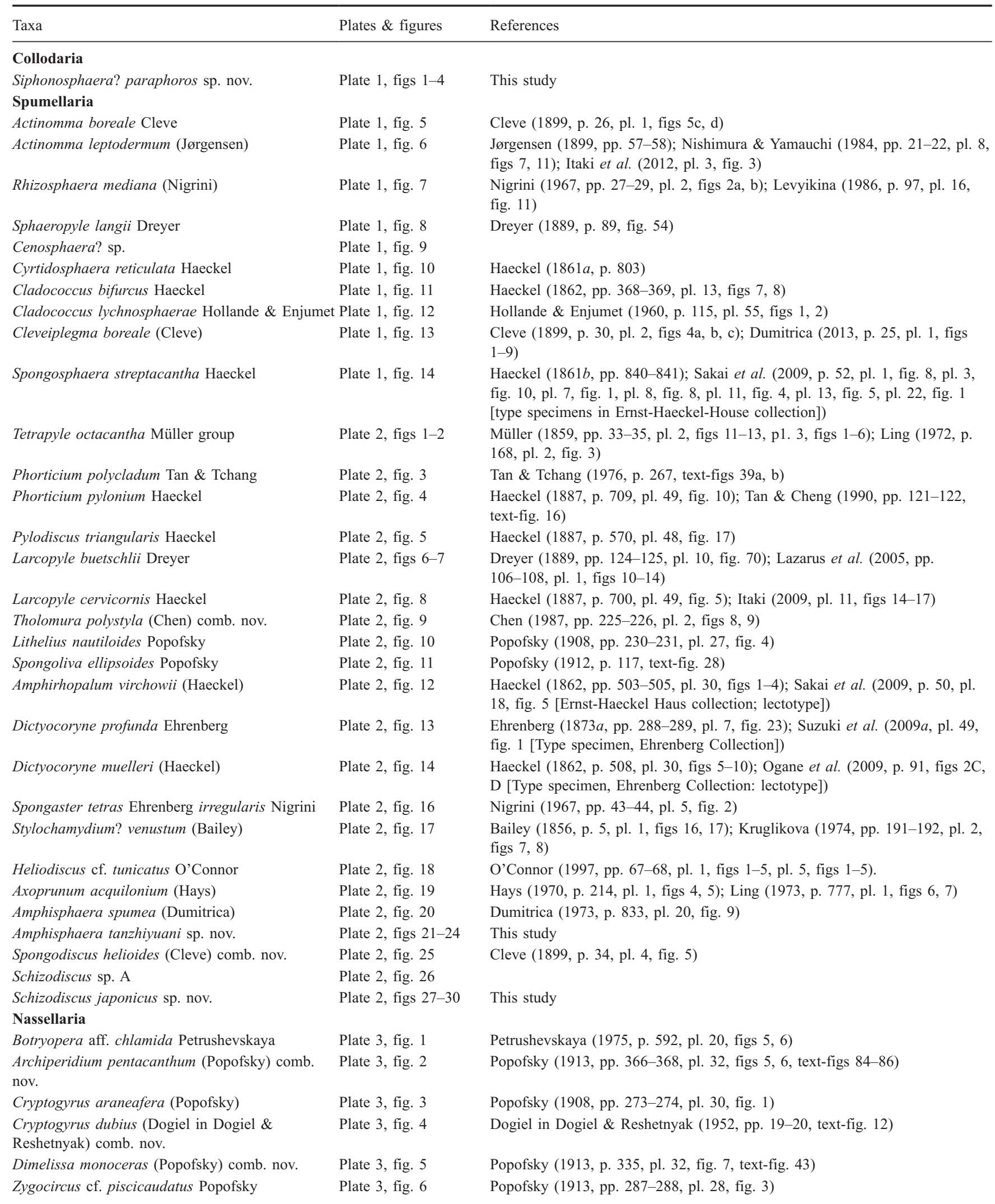


Table 1. (Continued)

\begin{tabular}{|c|c|c|}
\hline Taxa & Plates \& figures & References \\
\hline Ceratospyris problematica (Dogiel) & Plate 3, fig. 9 & Dogiel in Petrushevskaya (1969, p. 134, pl. 1, fig. 6) \\
\hline Cycladophora davisiana Ehrenberg & Plate 3, figs $10-12$ & $\begin{array}{l}\text { Ehrenberg (1873b, pp. } 288-289 \text {, pl. 2, fig. } 11) \text {; Suzuki et al. (2009a, pl. } 41 \text {, } \\
\text { fig. } 3 \text {, pl. } 42 \text {, figs. } 5 \text {, } 9 \text { [Type specimen, Ehrenberg Collection]) }\end{array}$ \\
\hline Theocorythium trachelium (Ehrenberg) & Plate 3, fig. 14 & $\begin{array}{l}\text { Ehrenberg (1861, p. } 768) \text {; Suzuki et al. (2009a, pl. 55, fig. } 4 \text { [Type specimen, } \\
\text { Ehrenberg Collection]) }\end{array}$ \\
\hline Ceratocyrtis spinosiretis (Takahashi) comb. nov. & Plate 3, fig. 15 & $\begin{array}{l}\text { Takahashi (1991, p. 110, pl. 34, figs 1, 2, 7); Itaki (2009, p. 52, pl. 19, figs } \\
\text { 3-10) }\end{array}$ \\
\hline Lamprocyclas maritalis Haeckel & Plate 3, fig. 16 & $\begin{array}{l}\text { Haeckel (1887, p. 1390, pl. 74, figs 13, 14); Renz (1976, p. 145, pl. 6, fig. } \\
\text { 26) }\end{array}$ \\
\hline
\end{tabular}

Remarks. Spongoliva ellipsoides is commonly reported from various tropical to mid-latitudinal regions globally, but the range of this species is poorly documented except for our report.

\section{Ceratospyris problematica Interval Zone (131-33 ka)}

Definition. Base of zone is defined by the FO of Ceratospyris problematica. Top of zone defined by the base of the Acanthodesmia vinculata Interval Zone.

Faunal character. This zone is characterized by several bioevents, such as the LO of Schizodiscus sp. A. (86 ka), AP3 of Lychnocanoma sakaii (61 ka), RD of L. sakaii (55ka) and LO of L. sakaii $(33 \mathrm{ka})$.

Interval and age. The stratigraphical interval between sample $8 \mathrm{H}-6$ at $42-48 \mathrm{~cm}(70.85 \mathrm{mbsf})$ and $3 \mathrm{H}-4$ at $42-48 \mathrm{~cm} \mathrm{(20.91} \mathrm{mbsf)} \mathrm{of} \mathrm{the}$ 902-C9001C core. This zone covers the period from 131 to $33 \mathrm{ka}$.

Remarks. Ceratospyris problematica has not been identified from other regions previously, except for the original description by Petrushevskaya (1969). We confirm this species here and its stratigraphical range (Fig. 5).

\section{Acanthodesmia vinculata Interval Zone (33-0 ka)}

Definition. Base of zone defined by the LO of Lychnocanoma sakaii. Top of zone not defined - top of the core $(0 \mathrm{mbsf})$.

Faunal character. All the species that occur in the previous zone are found in this zone. The FCO of Acanthodesmia vinculata $(17 \mathrm{ka})$ and the reappearance of Amphisphaera tanzhiyuani sp. nov. occur in this interval zone.

Interval and age. The stratigraphical interval between sample $3 \mathrm{H}-4$ at $42-48 \mathrm{~cm}(20.91 \mathrm{mbsf})$ and the top of core $902-\mathrm{C} 9001 \mathrm{C}$ $(0 \mathrm{mbsf})$. This zone covers the period from 33 to $0 \mathrm{ka}$.

Remarks. Acanthodesmoidea vinculata is well recorded in the Upper Pleistocene sediments (Nishimura \& Yamauchi, 1984; Bjørklund \& de Ruiter, 1987).

\section{CORRELATION OF RADIOLARIAN BIOEVENTS IN THE NORTHWESTERN PACIFIC SINCE THE MIDDLE PLEISTOCENE}

Based on thorough examination of the distribution of radiolarian species within the 902-C9001C core, eight radiolarian regional zones are proposed for the past $740 \mathrm{ka}$ within the Shimokita region (northwestern Pacific off the east coast of northern Japan). As seven bioevents in this region were first recognized in the present study, direct comparison with previously established zones in the North Pacific was necessary to locate these new radiolarian zones against the North Pacific standard radiolarian zonation for the Quaternary period established by Kamikuri et al. $(2004,2007)$ and Motoyama et al. (2004). These studies proposed a Neogene radiolarian biostratigraphy for the North Pacific in which the Middle to Upper Pleistocene comprised only two radiolarian zones: the Stylatractus universus Zone and the Botryostrobus aquilonaris Zone, which were defined by the LO of Eucyrtidium matuyamai at $1050 \mathrm{ka}$ and by the LO of S. universus at $430 \mathrm{ka}$, respectively (e.g. Motoyama et al. 2004; Fig. 5). In the present study, a major problem regarding these last datums was identified, as $S$. universus was not recorded at the study site, despite the fact that the LO of $S$. universus has been established as the tie point in the Middle Pleistocene within the North Pacific. This absence indicates that this datum is not always applicable in regions within the North Pacific, and that updates to the North Pacific radiolarian zonation are necessary in order to determine the regional suitability of each datum. Figure 5 shows the updates in which the radiolarian zones identified in the present study have been compared to the East Japan radiolarian zonations (after Motoyama et al. 2004; Kamikuri et al. 2007) and the Sea of Okhotsk radiolarian zonation (after Matul et al. 2002).

The S. universus Zone established by Motoyama et al. (2004), which was defined by the LO of E. matuyamai at $1050 \mathrm{ka}$ (Base) and by the LO of $S$. universus at $430 \mathrm{ka}$ (Top), was correlated with the A. acquilonium Zone established by Matul et al. (2002). The LO of A. acquilonium defined the top of this zone at $330 \mathrm{ka}$. Matul et al. (2002) determined that $S$. universus was not present in the 
K. M. Matsuzaki et al.

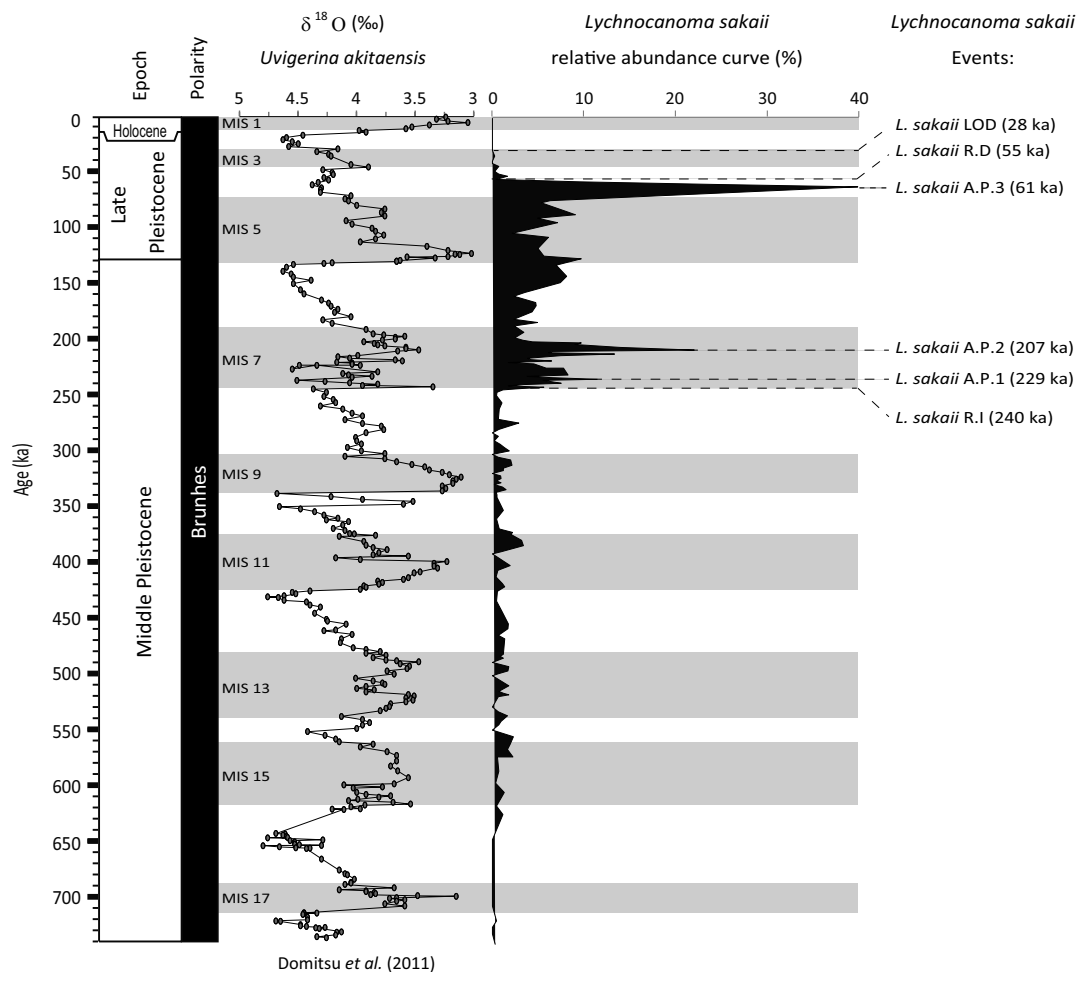

Fig. 4. Lychnocanoma sakaii abundance curve serving as a possible stratigraphical tool in the northwestern Pacific. Rapid increase (RI) at 240 ka, rapid decrease (RD) at $55 \mathrm{ka}$, and the three highest abundances peaks at $229 \mathrm{ka}$ (AP1), $207 \mathrm{ka}$ (AP2) and $61 \mathrm{ka}$ (AP3) serving as alternative stratigraphical proxies in the northwestern Pacific. LOD, last occurrence datum.

Table 2. Radiolarian events in the northwestern Pacific (core 902-9001C).

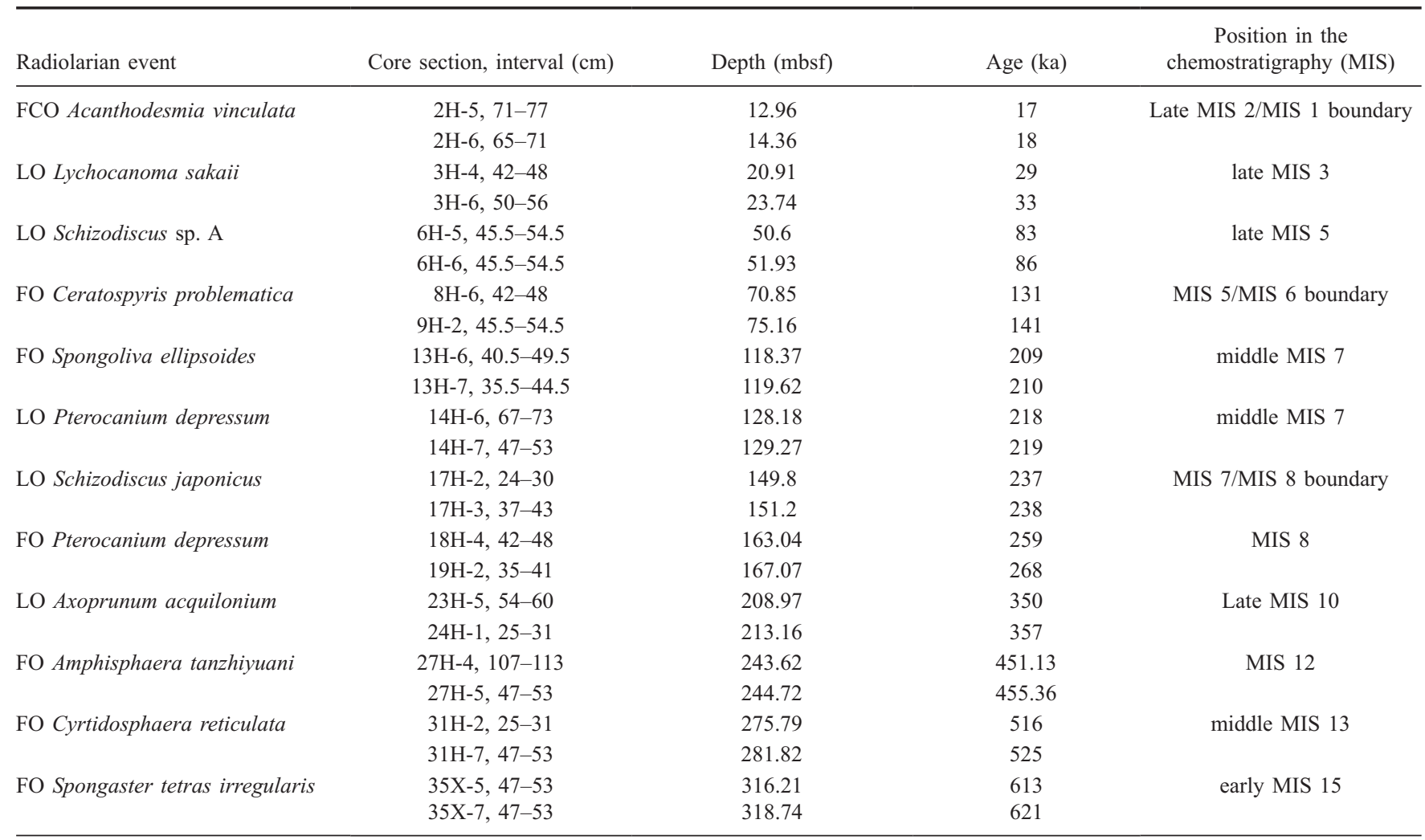

FOD, first occurrence datum; LO, last occurrence datum; FCO, first continuous occurrence. 


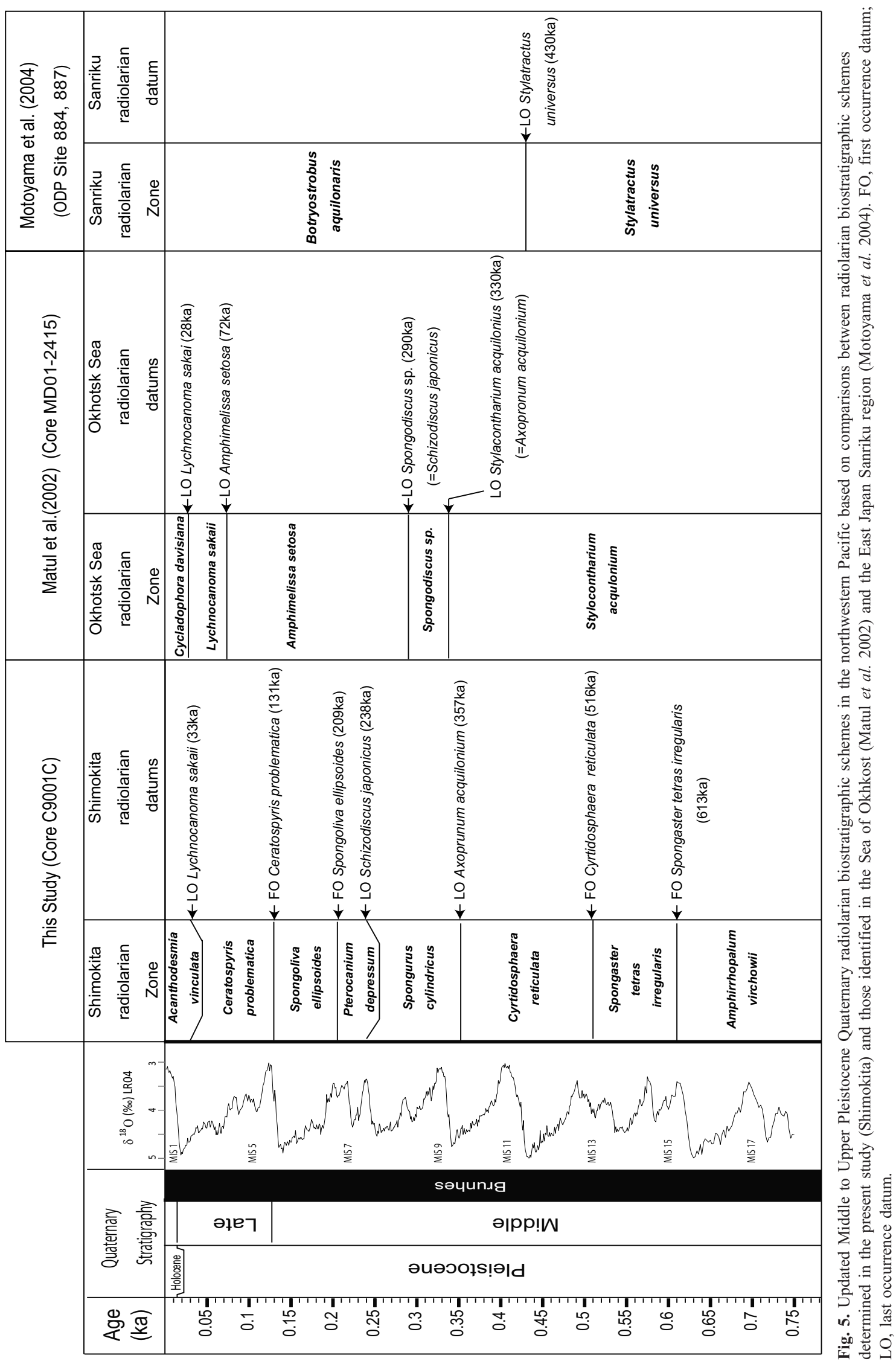


Table 3. Lychnocanoma sakaii events - rapid increase (RI), rapid decrease (RD) and abundance peaks (AP) serving as alternative stratigraphic proxies within the northwestern Pacific Middle to late Pleistocene.

\begin{tabular}{|c|c|c|c|c|}
\hline Radiolarian event & Core section, interval (cm) & Depth (mbsf) & Age (ka) & Position in the chemostratigraphy (MIS) \\
\hline Lychocanoma sakaii $\mathrm{RD}$ & $5 \mathrm{H}-1,45.5-54.5$ & 35.86 & 55 & late MIS 4 \\
\hline Lychocanoma sakaii AP3 & $5 \mathrm{H}-4,45.5-54.5$ & 39.74 & 61 & middle MIS 4 \\
\hline Lychocanoma sakaii AP1 & $16 \mathrm{H}-2,10-16$ & 140.33 & 229 & early MIS 7 \\
\hline Lychocanoma sakaii RI & $17 \mathrm{H}-4,37-43$ & 152.47 & 240 & MIS 8/MIS 7 boundary \\
\hline
\end{tabular}

Sea of Okhotsk. The A. acquilonium Zone correlated with three of the radiolarian zones identified in the present study. An A. virchowii Zone (c. $613 \mathrm{ka}$ ), which would cover the lower part of the A. acquilonium Zone, as defined by Matul et al. (2002), could serve to cover this interval. The middle part of the $A$. acquilonium Zone established by Matul et al. (2002) correlates with the $S$. tetras irregularis Zone (613-516ka) herein (Fig. 5). The C. reticulata Zone (516-357ka) covers the top of the A. acquilonium Zone of Matul et al. (2002). The LO of A. acquilonium determined at our study site $(357 \mathrm{ka})$ was relatively synchronous with the LO of the same species observed in the Sea of Okhotsk ( $330 \mathrm{ka})$.

The B. aquilonaris Zone of Motoyama et al. (2004) and defined by the LO of $S$. universus at $430 \mathrm{ka}$ correlates with four radiolarian zones in the Sea of Okhotsk (Matul et al. 2002); in the present study the $B$. acquilonaris Zone correlates with five radiolarian zones. The base of the B. acquilonaris Zone correlated with the Spongodiscus sp. Zone established by Matul et al. (2002), which was defined by the LO of $A$. acquilonium (330 ka) (Base) and the LO of Spongodiscus sp. (Schizodiscus japonica sp. nov.) at $290 \mathrm{ka}$ (Top). The Spongodiscus sp. Zone of Matul et al. (2002) correlates with the Spongurus cyclindrica Zone (357-259ka) newly established in the present study, which was defined by the interval between the LO of A. acquilonium (357 ka) and the base of the $P$. depressum Zone (238ka) (Fig. 5). The middle part of the $B$. acquilonaris Zone correlates with the Amphimelissa setosa Zone established by Matul et al. (2002) in the Sea of Okhotsk as defined by the LO of Spongodiscus sp. at $290 \mathrm{ka}$ and the LO of $A$. setosa at $72 \mathrm{ka}$ (Fig. 5). This only correlated with the zones identified in the present study in an indirect manner, as $A$. setosa was not included in our analysis due to its small size $(<60 \mu \mathrm{m})$. Based on the numerical ages of Domitsu et al. (2011), it was determined that the A. setosa Zone would correlate with the $P$. depressum Zone $(238-209 \mathrm{ka})$ in C9001C. The base of the P. depressum Zone was defined by the LO of Schizodiscus japonicus (238ka). A time gap of nearly $50 \mathrm{ka}$ existed between the LOs of S. japonicus sp. nov. (Spongodiscus sp. in Matul et al. 2002) determined at the present study site and in the Sea of Okhotsk (Matul et al. 2002). This time gap demonstrates that the LOs of S. japonicus sp. nov. at these two sites were not synchronous. The middle part of the A. setosa Zone in the Sea of Okhotsk was correlated with the S. ellipsoides Zone (209-131 ka) identified in the present study as defined by the FO of $S$. ellipsoides $(209 \mathrm{ka})$.

The upper part of the B. acquilonaris Zone (Motoyama et al. 2004) correlates with the L. sakaii Zone in the Sea of Okhotsk, which was defined by the LOs of $A$. setosa at $72 \mathrm{ka}$ and $L$. sakaii at $28 \mathrm{ka}$ (Matul et al. 2002),. This zone also correlates with the upper part of the C. problematica Zone (131-33 ka), which was defined in the present study by the FO of $C$. problematica at $131 \mathrm{ka}$ and LO of L. sakaii at $33 \mathrm{ka}$. These results demonstrate that the LO of L. sakaii appears to be synchronous in both the Shimokita region and the Sea of Okhotsk within a time gap of $5 \mathrm{ka}$.

\section{CONCLUSIONS}

In the present study, a high-resolution Middle to Upper Pleistocene radiolarian biostratigraphical scheme is established for the northwestern Pacific. We confirmed continuous stratigraphical occurrences of 74 radiolarian species and identified 38 of these as useful for biostratigraphical purposes. Furthermore, three new species were described (Amphisphaera tanzhiyuani sp. nov., Schizodiscus japonicus sp. nov. and Siphonosphaera? paraphoros sp. nov.). A total of 12 bioevents were identified during the past $740 \mathrm{ka}$ and were used in the establishment of eight new Pleistocene radiolarian zones. Dates were based on the age model of Domitsu et al. (2011). Of the 12 events identified, 12 had never been previously identified in the northwestern Pacific. The newly established radiolarian zones were compared with zonations previously proposed in the northwestern Pacific and the Sea of Okhotsk by Matul et al. (2002), Motoyama et al. (2004) and Kamikuri et al. (2007). It was noted that the well-known Stylatractus universus LO, which has served as one of the most synchronous datum levels throughout the North Pacific, could not be used, as the species was absent in both the Shimokita site and the Sea of Okhotsk. This suggested that these sites were located outside the northwestern distribution limit of $S$. universus. Therefore, it was determined that the LO of $S$. universus was not a suitable datum for use in the western margin of the northwestern Pacific in North Japan and the Sea of Okhotsk. Instead of the LO of $S$. universus, the following three datums were determined to be important with respect to the Pleistocene: the LOs of A. aquilonium (357ka), S. japonicus (238ka) and L. sakaii (33 ka). Additionally, the abundance curve of L. sakaii was identified as a potentially useful stratigraphical tool within Middle Pleistocene sediments in the northwestern Pacific due to its rapid decrease datum (RD; $55 \mathrm{ka})$, rapid increase datum (RI; $240 \mathrm{ka})$ and three abundance peaks (229ka (AP1), $207 \mathrm{ka} \mathrm{(AP2)} \mathrm{and} 61 \mathrm{ka}$ (AP3)), which could serve as synchronous events within the region.

\section{ACKNOWLEDGEMENTS}

The authors thank Drs K. R. Bjørklund and J. Gregory for their helpful reviews and the Japan Agency for Marine-Earth Science and Technology (JAMSTEC) for providing the samples. This research was supported by the Japan Society for the Promotion of Science, Tohoku University International Advanced Research and Education Organization and Global Center of Excellence Program on Global Education and Research Center for Earth and Planetary Dynamics at Tohoku University (Leader E. Ohtani) financed by the Ministry of Education, Culture, Sports, Science, and Technology of Japan. 
Manuscript received 21 May 2013

Manuscript accepted 5 December 2013

Scientific Editing by John Gregory

\section{REFERENCES}

Abelmann, A. \& Nimmergut, A. 2005. Radiolarians in the Sea of Okhotsk and their ecological implication for paleoenvironmental reconstitutions. Deep-Sea Research Part II: Topical Studies in Oceanography, 52: 2302-2331.

Alexandrovich, J. M. 1992. Radiolarians from Sites 794, 795, 796, and 797 (Japan Sea). In Tamaki, K., Ingle, J. C. J. et al. (Eds), Proceedings of the Ocean Drilling Program, Scientific Results, 127-128. Ocean Drilling Program, College Station, TX: 291-307.

Bailey, J. W. 1856. Notice of microscopic forms found in the soundings of the Sea of Kamchatka-with a plate. American Journal of Science Arts Series, 2: 1-6.

Bjørklund, K. R. \& de Ruiter, R. 1987. Radiolarian preservation in eastern Mediterranean anoxic sediments. Marine Geology, 75: 271-281.

Campbell, A. S. 1954. Radiolaria. In Moore, R. C. (Ed.), Treatise on Invertebrate Paleontology, Part D Protista 3. Protozoa (Chiefly Radiolaria and Tintinnina). Geological Society of America and University of Kansas Press, Kansas, 163pp.

Campbell, A. S. \& Clark, B. L. 1944. Miocene Radiolarian Faunas from Southern California. Geological Society of America, Special Papers, 51, $76 \mathrm{pp}$.

Chen, M. H. \& Tan, Z. Y. 1996. Radiolaria from Surface Sediments of the Central and Northern South China Sea. Science Publishing House, Beijing, 271pp.

Chen, W.-b. 1987. Some new species of Radiolaria from surface sediments of the East China Sea and the South China Sea. Chinese Journal of Oceanology and Limnology, 5: 222-227.

Cleve, P. T. 1899. Plankton collected by the Swedish Expedition to Spitzbergen in 1898. Kongliga Svenska Vetenskaps-Akademiens Handlingar, 32: 1-51.

Dogiel, V. A. \& Reshetnyak, V. V. 1952. Material on Radiolarians of the northwestern part of the Pacific Ocean. Issledovaniya Dalnevostochnykh Morei SSSR, 3: 5-36.

Domitsu, H., Uchida, J. et al. 2011. Stratigraphic relationships between the last occurrence of Neogloboquadrina inglei and marine isotope stages in the northwest Pacific, D/V Chikyu Expedition 902, Hole C9001C. Newsletters on Stratigraphy, 44: 113-122.

Dreyer, F. 1889. Die Pylombildungen in vergleichend-anatomischer und entwicklugs-geschichtlicher Beziehung bei Radiolarien und bei Protisten überhaupt, nebst System und Beschreibung neuer und der bis jetzt bekannten pylomatischen Spummellarien. Jenaische Zeitschrift für Naturwissenschaft herausgegeben von der medizinisch-naturwissenschaftlichen Gesellschaft zu Jena, 23: 77-214.

Dumitrica, P. 1973. Cretaceous and Quaternary Radiolaria in deep sea sediments from the northwest Atlantic Ocean and Mediterranean Sea. In Ryan, W. B. F., Hsu, K. J. et al. Initial Reports of the Deep Sea Drilling Project, 13. US Government Printing Office, Washington, DC: 829-901.

Dumitrica, P. 2013. Cleveiplegma nov. gen., a new generic name for the radiolarian species Rhizoplegma boreale (Cleve, 1899). Revue de Micropaléontologie, 56: 21-25.

Ehrenberg, C. G. 1854. Mikrogeologie. Voss, Leipzig, 374pp.

Ehrenberg, C. G. 1861. Über die organischen und unorganischen Mischungsverhältnisse des Meeresgrundes in 19800 Fuss Tiefe nach Lieut. Brookes Messung. Monatsberichte der Königlich Preußischen Akademie der Wissenschaften zu Berlin, 1860: 765-774.

Ehrenberg, C. G. 1862. Über die Tiefgrund-Verhältnisse des Oceans am Eingange der Davisstraße und bei Island. Monatsberichte der Königlich Preußischen Akademie der Wissenschaften zu Berlin, 1861: 275-315.
Ehrenberg, C. G. 1873a. Mikrogeologische Studien als Zusammenfassung seiner Beobachtungen des kleinsten Lebens der Meeres-Tiefgründe aller Zonen und dessen geologischen Einfluss. Monatsberichte der Königlich Preußischen Akademie der Wissenschaften zu Berlin, 1872: 265-322.

Ehrenberg, C. G. 1873b. Mikrogeologische Studien über das kleinste Leben der Meeres-Tiefgründe aller Zonen und dessen geologischen Einfluss. Abhandlungen Königlichen Akademie der Wissenschaften zu Berlin, 1872: 131-399.

Ehrenberg, C. G. 1876. Fortsetzung der mikrogeologischen Studien als Gesammt-Übersicht der mikroskopischen Paläontologie gleichartig analysirter Gebirgsarten der Erde, mit specieller Rücksicht auf den Polycystinen-Mergel von Barbados. Abhandlungen der Königlichen Akademie der Wissenschaften zu Berlin, 1875: 1-226.

Haeckel, E. 1861a. Über neue, lebende Radiolarien des Mittelmeeres und legte die dazu gehörigen Abbildungen. Monatsberichte der Königlich Preußischen Akademie der Wissenschaften zu Berlin, 1860: 794-817.

Haeckel, E. 1861b. Fernere Abbildungen und Diagnosen neuer Gattungen und Arten von lebenden Radiolarien des Mittelmeeres. Monatsberichte der Königlich Preußischen Akademie der Wissenschaften zu Berlin, 1860: $835-845$.

Haeckel, E. 1862. Die Radiolarien (Rhizopoda Radiolaria). Eine Monographie. Tafel 1. Reimer, Berlin, 572pp.

Haeckel, E. 1882. Entwurf eines Radiolarien-Systems auf Grund von Studien der Challenger-Radiolarien. Jenaische Zeitschrift für Naturwissenschaft herausgegeben von der medizinisch-naturwissenschaftichen Gesellschaft zu Jena, 15: 418-472.

Haeckel, E. 1887. Report on the Radiolaria collected by H.M.S. Challenger during the years 1873-1876. Report on the Scientific Results of the Voyage of H.M.S. Challenger during the year 1873-1876, Zoology, 18: $1-1803$.

Hays, J. D. 1970. The stratigraphy and evolutionary trends of Radiolaria in north Pacific deep-sea sediments. In Hays, J. D. (Ed.), Geological Investigations of the North Pacific. Geological Society of America, Memoirs, 126: 185-218.

Hollande, A. \& Enjumet, M. 1960. Cytologie, évolution et systématique des Sphaeroïdés (Radiolaires). Archives du Muséum National d'Histoire Naturelle, Série, 7: 1-134.

Itaki, T. 2009. Last Glacial to Holocene Polycystine radiolarians from the Japan Sea. New of Osaka Micropaleontologist (NOM), Special Volume, 14: 43-89.

Itaki, T. \& Bjørklund, K. R. 2007. Bailey's (1856) radiolarian types from the Bering Sea re-examined. Micropaleontology, 52: 449-463.

Itaki, T., Kim, S., Rella, S. F., Uchida, M., Tada, R. \& Boo-Keun, K. 2012. Millennial-scale variations of late Pleistocene radiolarian assemblages in the Bering Sea related to environments in shallow and deep waters. Deep-Sea Research II, 61-64: 127-144.

Jørgensen, E. 1899. Protophyten und Protozoën im Plankton aus der norwegischen Westküste. Bergens Museums Ärbog, 1899: 51-95.

Kamikuri, S., Nishi, H., Motoyama, I. \& Saito, S. 2004. Middle Miocene to Pleistocene radiolarian biostratigraphy in the Northwest Pacific Ocean, ODP Leg 186. The Island Arc, 13: 191-226.

Kamikuri, S., Nishi, H. \& Motoyama, I. 2007. Effects of late Neogene climatic cooling on North Pacific radiolarian assemblages and oceanographic conditions. Palaeogeography, Palaeoclimatology, Palaeoecology, 249: 370-392.

Kamikuri, S. 2010. New late Neogene radiolarian species from the middle to high latitudes of the North Pacific. Revue de Micropaléontologie, 53: 85-106.

Kruglikova, S. B. 1974. Kharakternye vidy radiolayriy v donnykh osadkakh voreal'noi zony Tikhogo okeana. In Zhuze, A. P. (Ed.), Mikropaleontologiya Okeanov $i$ Morey. Akaemiya Nauk SSSR, Okeanograficheskaya Komissiya. Nauka, Moskova, 187-196.

Lazarus, D., Faust, K. \& Popova-Goll, I. 2005. New species of prunioid radiolarians from the Antarctic Neogene. Journal of Micropaleontology, 24: 97-121. 
Levyikina, I. E. 1986. Stratigrafiya Neogenobykh otlozheniy severozapadnoy chasti tikhogo okeana po radiolyariyam. Ordena Trudovogo Krasnogo Zhameni Geologicheskiy Institut Akademiya Nauk SSSR, 413: 1-117. [In Russian with English abstract.]

Ling, H. Y. 1972. Polycystine Radiolaria from surface sediments of the South China Sea and the adjacent seas of Taiwan. Acta Geologica Taiwanica, 2:159-178.

Ling, H. Y. 1973. Radiolaria: leg 19 of the Deep Sea Drilling Project. In Creager, J. S., Scholl, D. W. et al. (Eds), Initial Reports of the Deep Sea Drilling Project, 19. US Government Printing Office, Washington, DC: $777-797$.

Ling, H. Y. 1975. Radiolaria: leg 31 of the Deep Sea Drilling Project. In Karig, D. E., Ingle, J. C, Jr. et al. (Eds), Initial Reports of the Deep Sea Drilling Project, 3. US Government Printing Office, Washington, DC: 703-761.

Ling, H. Y. 1980. Radiolarians from the Emperor Seamounts of the northwest Pacific: Leg 55 of the Deep Sea Drilling Project. In Jackson, E. D., Koizumi, I. et al. (Eds), Initial Reports of the Deep Sea Drilling Project, 55. US Government Printing Office, Washington, DC: 365-373.

Matul, A., Abelmann, A., Tiedemann, R., Kaiser, A. \& Nürnberg, D. 2002. Late Quaternary polycystine radiolarian datum events in the Sea of Okhotsk. Geo-Marine Letters, 22: 25-32.

Matul, A. G., Abelmann, D., Nurnberg, D. \& Tiedemann, R. 2009. Stratigraphy and major paleoenvironmental changes in the Sea of Okhotsk during the last million years inferred from radiolarian data. Oceanology, 49: 93-100.

Morley, J. J. 1985. Radiolarians from the northwest Pacific, Deep Sea Drilling Project Leg 86. In Heath, G. R., Burckle, L. H. et al. (Eds), Initial Reports of the Deep Sea Drilling Project, 86. US Government Printing Office, Washington, DC: 399-422.

Morley, J. J. \& Nigrini, C. 1995. Miocene to Pleistocene radiolarian biostratigraphy of North Pacific Sites 881, 884, 885, 886 and 887. In Rea, D. K., Basov, I. A., Scholl, D. W. \& Allan, J. F. (Eds), Proceeding of the Ocean Drilling Program, Scientific Results, 145. Ocean Drilling Program, College Station, TX: 55-91.

Morley, J. J., Hays, J. D. \& Robertson, J. H. 1982. Stratigraphic framework for the late Pleistocene in the northwest Pacific Ocean. Deep-Sea Research, 29: 1485-1499.

Morley, J. J., Tiase, V. L., Ashby, M. M. \& Kashgarian, M. 1995. A highresolution stratigraphy for Pleistocene sediments from North Pacific sites 881,883 , and 887 based on abundances variation of the radiolarian Cycladophora davisiana. In Rea, D. K., Basov, I. A., Scholl, D. W. \& Allan, J. F. (Eds), Proceeding of the Ocean Drilling Program, Scientific Results, 145. Ocean Drilling Program, College Station, TX: 133-140.

Motoyama, I., Niitsuma, N. et al. 2004. Middle Miocene to Pleistocene magneto-biostratigraphy of ODP Sites 1150 and 1151, northwest Pacific: Sedimentation rate and updated regional geological timescale. The Island Arc, 13: 289-305.

Müller, J. 1856. Über die Thalassicollen, Polycystinen und Acanthometren des Mittelmeeres. Monatsberichte der Königlich Preußischen Akademie der Wissenschaften zu Berlin, 1856: 474-503.

Müller, J. 1859. Über die Thalassicollen, Polycystinen und Acanthometren des Mittelmeeres. Abhandlungen Königlichen Akademie der Wissenschaften zu Berlin, 1858: 1-62.

Nigrini, C. 1967. Radiolaria in pelagic sediments from the Indian and Atlantic oceans. Bulletin of the Scripps Institution of Oceanography, University of California, 11: 1-125.

Nishimura, A. \& Yamauchi, M. 1984. Radiolarians from the Nankai Trough in the northwest Pacific. News of Osaka Micropaleontologists, Special Volume, 6: 1-148.

O'Connor, B. 1997. New Radiolaria from the Oligocene and early Miocene of Northland, New Zealand. Micropaleontology, 43: 63-100.

Ogane, K., Suzuki, N., Aita, Y., Sakai, T. \& Lazarus, D. 2009. Ehrenberg's radiolarian collections from Barbados. National Museum of Nature and Science Monograph, 40: 97-106.
Okazaki, Y., Takahashi, K., Itaki, T. \& Kawasaki, Y. 2004. Comparison of radiolarian vertical distributions in the Okhotsk Sea near the Kuril Island and in the northwestern North Pacific off Hokkaido Island. Marine Micropaleontology, 51: 257-284.

Petrushevskaya, M. G. 1968. Gomologiya v skeletakh radiolyariy Nassellaria. 1. Osnovnye dugi v semeystve Cyrtoidae. Zoologicheskyiy Zhurnal, 47: 1296-1310. [In Russian.]

Petrushevskaya, M. G. 1969. Radiolyarii Spumellaria i Nassellaria $\mathrm{v}$ donnykh osadkakh kak indikatory gidrologicheskikh usloviy. In Zhuze, A. P. (Ed.), Osnovnyie Problemyi Mikropaleontologii $i$ Organogennogo Osadkonakopleniya v Okeanakh i Moryakh. K VIII kongressu Inqua, Parizh, 1969: 127-152. Akademiya Nauk SSR, Okeanograficheskaya Komssiya. Nauka, Moscow. [In Russian with English abstract.]

Petrushevskaya, M. G. 1975. Cenozoic radiolarians of the Antarctic, Leg 29, DSDP. In Kennet, J. P. \& Houtz, R. E. (Eds), Initial Reports of the Deep Sea Drilling Project, 29. US Government Printing Office, Washington, DC: 541-675.

Petrushevskaya, M. G. 1984. O kalssifikatsii radiolyariy Polycystina. In Petrushevskaya, M. G. \& Stepyan'yand, S. D. (Eds), Morfologiya, Ekologiya i Evolyutsiya Radiolyariyi. Nauka, Leningrad, 124-148.

Popofsky, A. 1908. Die Radiolarien der Antarktis (mit Ausnahme der Tripyleen). Deutsche Südpolar-Expedition 1901-1903. Zoologie, 10: 185-305.

Popofsky, A. 1912. Die Sphaerellarien des Warmwassergebietes. Deutsche Südpolar-Expedition 1901-1903, Zoologie II, 13: 73-159.

Popofsky, A. 1913. Die Nassellarien des Warmwassergebietes. Deutsche Südpolar-Expedition 1901-1903. Zoologie, 14: 216-416.

Renz, G. W. 1976. The distribution and ecology of Radiolaria in the central Pacific: Plankton and surface sediments. Bulletin of the Scripps Institution of Oceanography, University of California, 22: 1-267.

Sakai, T. 1980. Radiolarians from Sites 434, 435 and 436, northwest Pacific, Leg. 56, DSDP. In Scientific Party, Initial Reports of the Deep Sea Drilling Project, 56-57. US Government Printing Office, Washington, DC: 695-733.

Sakai, T., Suzuki, N., Ogane, K., Lazarus, D., Breidbach, O. \& Bach, T. 2009. Haeckel's Messina radiolarian collection housed in the ErnstHaeckel-Haus. National Museum of Nature and Science Monographs, 40: $47-54$.

Sugiyama, K., Nobuhara, T. \& Inoue, K. 1992. Preliminary report on Pliocene radiolarians from the Nobori Formation, Tonohama Group, Shikoku, Southwest Japan. Journal of Earth and Planetary Sciences, Nagoya University, 39: 1-30.

Suzuki, N., Ogane, K., Aita, Y., Sakai, T. \& Lazarus, D. 2009a. Reexamination of Ehrenberg's Neogene radiolarian collections and its impact on taxonomic stability. National Museum of Nature and Science Monograph, 40: 87-96.

Suzuki, N., Ogane, K. \& Chiba, K. 2009b. Middle to Eocene polycystine radiolarians from the Site 1172, Leg 189, Southwest Pacific. News of Osaka Micropaleontologists, Special Volume, 14: 239-296.

Takahashi, K. 1991. Radiolaria: Flux, ecology, and taxonomy in the Pacific and Atlantic. Ocean Biocoenosis Series, 3: 1-301.

Tan, Z. \& Tchang, T. 1976. Studies on the Radiolaria of the East China Sea. II. Spumellaria, Nassellaria, Phaeodaria, Sticholonchea. Studia Marina Sinica, 11: 217-310. [In Chinese with English abstract.]

Tan, Z.-y \& Chen, M.-h. 1990. Some new revisions of Pyloniidae. Chinese Journal of Oceanology and Limnology, 8: 109-125.

Tan, Z.-y \& Su, X.-G. 1982. Studies on the Radiolaria in sediments of the East China Sea (continental shelf). Studia Marina Sinica, 19: 129-216.

Tanaka, S. \& Takahashi, K. 2008. Detailed vertical distribution of radiolarian assemblage $(0-3000 \mathrm{~m}$, fifteen layers) in the central subarctic Pacific, June 2006. Memoirs of the Faculty of Science, Kyushu University. Series D, Earth and Planetary Sciences, 32: 49-72. 